\title{
A obra de Francisco Fidalgo Villaveirán
}

\author{
XoÁn Babarro GonZález \\ Catedrático de Lingua e Literatura Galega de Ensino Medio \\ xoanbabarro@hotmail.com \\ Recibido: diciembre de 2013. Aceptado: enero de 2014
}

\begin{abstract}
Resumo: Os escritores galegoasturianos da Xeración de 1936, que ven a súa produción truncada polos condicionantes sociopolíticos e culturais impostos tras da Guerra Civil, desenvolven unha literatura cunha forte presenza de temas locais redactados nas diferentes variantes lingüísticas da zona; ao tempo que manteñen, uns en maior grao que outros, como referente o sistema literario común de Galicia. Neste contexto áchase a obra de Francisco Fidalgo Villaveirán, un autor que realizou incursións, en diferentes épocas, no teatro, na poesía e na narración.
\end{abstract}

Palabras clave: Literatura galega, Xeración galegoasturiana de 1936, teatro, sainete, Fidalgo Villaveirán, variantes dialectais.

\begin{abstract}
The Galician-Asturian writers from the 1936 Generation, that saw their art stifled by the cultural and socio-political circumstances imposed after the civil war, developed a literature with a noticeable presence of local themes that are written within the diverse linguistic variations of the area. At the same time, they maintained as a model (although some to a greater degree than others) common literary system of Galicia. Within this context resides the work of Francisco Fidalgo Villaveirán, an author who throughout different periods of time made incursions into drama, poetry and narrative prose.
\end{abstract}

Keywords: Galician Literature, 1936 Galician-Asturian Generation, theatre, one-act comedy, Fidalgo Villaveirán, dialectal variations.

\section{INTRODUCIÓN}

Un dos trazos que acompaña a literatura galegoasturiana da maior parte do século XX é o de ser transmitida a través da prensa periódica, de programas de festas, de copias mecanografadas ou manuscritas e outros soportes similares. De tal xeito, que, á falta de bos arquivos que recolleran para o futuro todas as publicacións comarcais, ese tipo de difusión vén constituíndo un dos maiores obstáculos para termos unha visión completa dos autores; tanto por apareceren os textos baixo cabeceiras diferentes, como por conservárense semiabandona- 
dos en coleccións privadas. Outra característica desta área xeográfica é que, por encontrarse baixo administración asturiana, a recuperación do idioma non evolucionou á par que o resto de Galicia e este feito condicionou profundamente a súa normalización en todos os campos. Ata o punto de que, a oficialidade conseguida nas catro provincias, resulta, neste momento, unha verdadeira utopía contemplala para os dezaoito concellos galegoasturianos. Desta maneira, ao longo do século $\mathrm{XX}$, fronte a autores que asumen, en maior ou menor grao, o sistema literario común, tanto nos temas coma na lingua utilizada, achamos outros que manteñen a variante dialectal familiar unida, na maior parte dos casos, a motivos de carácter costumista. Vacilando entre as dúas posturas encóntranse os escritos que aquí presentamos de Francisco Fidalgo Villaveirán, un autor plenamente encarnado na vida e na cultura das terras mariñás de entre o Navia e o Eo, que viu a súa produción vernácula truncada polos condicionantes socioculturais impostos tras da Guerra Civil.

\subsection{Aproximación biobibliográfica}

Francisco Fidalgo Villaveirán nace en El Franco, parroquia de Valdepares, o 16 de novembro de 1913 e falece en Oviedo o día 29 de marzo de 1998. Era fillo de María del Pilar Villaveirán Fernández, natural e veciña de El Franco e de Liborio Fidalgo Blanco, orixinario da vila zamorana de Manganeses de la Polvorosa (Libro 13 de bautismos de Valdepares, folios 45, 46 e 48). Por motivos do traballo da súa nai, Paco irá moi pronto vivir ás Figueiras (Castropol), sen abandonar a estreita relación que o unía aos avós maternos, con quen se criara de pequeno. Nos seus escritos afloran a miúdo os recordos de infancia e xuventude...

Mi niñez va unida a la Iglesia y al atrio, lugar de mis juegos y travesuras, como al subirnos a las acacias en día de lluvia esperando que alguien pasara por debajo para agitar las ramas y cayera sobre el viandante un torrente de agua y creyendo que la lluvia arreciaba tapaba la cabeza con las manos y echaba a correr diciento en voz alta: «Coño, como chove y tá arreciando». (Do Pregón de las fiestas de la Virgen del Carmen y del Corpus de Figueiras de 1995)

Las zanjas abiertas para los cimientos sirvieron a los niños para jugar al quedas y al escondite, Pepe y Julián de Sante, Pepe Carnero y varios más, y recuerdo que por aquellos días yo sufría la enfermedad infantil de las paperas. (De «La Torre-Reloj y las Escuelas. Pequeñas historias de Figueras»)

Don Inocencio Cotarelo, párroco y doctor en Teología que desde 1900 hasta 1927 regentó la parroquia figuerense y en el verano me daba clases de matemáticas y fue el que ofreció la oración fúnebre en 1911 cuando la inauguración en Castropol de la estatua del marino Villamil. Y Martiniano Pérez Sanjurjo, representante de la medicina moderna arrebatado por la muerte en plena juventud, y doña Clementina, la profesora por cuyas clases pasamos varias generaciones. (Do Pregón de las fiestas de la Virgen del Carmen y del Corpus de Figueiras de 1995) 
A guisa de marco político señalemos que en España gobernaba la monarquía bajo el reinado de D. Alfonso XIII y aún pasarían once meses para la implantación de la República. La política estaba al rojo vivo, mas a los figuerenses nos importaba un pito lo que ocurría en Madrid y sus aledaños. Bastante teníamos con aguantar las órdenes de Castropol y la vigilancia del guardia municipal Parapar, que cumplía las ordenanzas a rajatabla y a las nueve de la noche ningún niño podía andar por la calle bajo pena de un bastonazo y la carrera subsiguiente. Dos carabineros componían la vigilancia del puerto y el cuartel residía en la calle de la Alameda en el edificio que es hoy Bar Andorra. Los niños de la escuela mirábamos el retrato del Rey y era popular la exclamación «iCoyois ten el Rey!», usando la sinalefa [de] «iQue oyois ten el Rey!» (perdóneme el lector por el taco). Nos reíamos de lo lindo diciendo y haciendo travesuras. Don Jesús Breña era el Maestro. (De «El domingo de los sopapos en Barres -pequeñas historias-»)

Activo colaborador durante a súa mocidade en diferentes empresas culturais, Paco conta co honor de ser un dos fundadores da biblioteca das Figueiras ${ }^{1}$ e de estar presente na creación do xornal figueirense Atalaya, que aparece baixo a dirección de Carlos P. Sanjurjo ${ }^{2}$.

Francisco examínase de Maxisterio en Oviedo e cursa estudos de bacharelato no primitivo instituto de Ribadeo, centro onde se seguiu formando cando xa exercía de mestre (recórdese que daquela os estudos de Maxisterio non se axustaban ao modelo actual). Na p.73 do Libro de Actas de Claustro, que recolle de 1928 a 1937, acta de 28 de abril de 1934, descubrimos que entre as matrículas gratuítas que se conceden para os exames do mes de xuño figura Francisco Fidalgo Villaveirán con tres (na acta correspondente de 1933 aparece tamén un Francisco Fidalgo con cinco). Igual ca outros alumnos e alumnas deste centro, Paco servíase das lanchas que enlazaban As Figueiras con Ribadeo. Nalgunha

1 Do seu labor como bibliotecario encontramos varias noticias na prensa da época (El Aldeano, n. ${ }^{\circ}$ 53, 15-XII-1931; n. ${ }^{\circ}$ 54, 30-XII-1931; n. . 59, 15-III-1932).

2 O primeiro número, despois de consideralo como «un buen exponente del alto nivel intelectual alcanzado por la juventud de la villa hermana», era recibido cunha ampla reseña no castropolense El Aldeano (n. ${ }^{\circ} 88,31-\mathrm{I}-1933$ ): «No es cosa de hacer comparaciones, odiosas siempre, pero, no obstante, diremos que lo que más nos ha interesado de ese primer número fue el cuento infantil «El zapatito de plata», recogido por «un insipiente», que esperamos continúe esa labor en números sucesivos, pues tiene para ello pluma y sensibilidad adecuadas. Unos «Apuntos sobre Beethoven» firmados por Don Juan de Carillana, demuestran un buen conocimiento de la vida del gran músico, están muy bien escritos y se leen con agrado. «Siluetas» y «Run-Run», dos se[c]ciones de anécdotas locales, tendrán numerosos y asiduos lectores, y no sólo en Figueras, pues la popular figura que aparece retratada en la primera es tan popular aquí como en la vecina villa. Informaciones abundantes de Castropol, Las Campas, Tol, Navia y Figueras, y un artículo humorístico de Barres, dan fe de que ha de ser realidad lo prometido a este respecto en el «Preámbulo» firmado por «La Redacción», muy interesante, así como los «Arpegios» del conocido poeta Amador F. Mejeras. Tenemos la seguridad de que «Atalaya» obtendrá en Figueras y en otros puntos el apoyo que merece, y que en consecuencia, tenga una larga y fecunda existencia». 
ocasión, o instituto chegou a solicitar xornada intensiva para que os alumnos que asistían ás clases por oficial non tivesen que cruzar a ría de noite 3 .

Comeza exercendo a docencia como interino na escola nacional mixta de Mántaras, no concello de Tapia de Casarego, na que permanece desde 2-IV1933 ata 11-XI-1934. A continuación, como «cursillista» de 1933, é nomeado mestre da escola nacional de Boal con data de 12-XI-1934, destino que mantén ata $31-\mathrm{X}-1943^{4}$. Despois, por un concurso de traslados, obtén praza na de nenos de Pazos, na parroquia de Iria (Padrón), onde exerce desde 17-I-1944 ata 31-XII-1945. Superadas as oposicións convocadas por unha orde ministerial de 5-III-1945 para cubrir vacantes de direccións de graduadas anexas ás escolas de Maxisterio, toma posesión como director da de Lugo o 3-I-1946, onde se mantén ata o 31-VIII-1950. Este cargo levaba implícito ser profesor de Prácticas da Normal, materia que el impartiu aos futuros mestres e que sintetizou no libriño Prácticas de Enseñanza. Orientaciones, publicado na capital lucense en 1950. Por unha orde ministerial de 3-V-1950 é nomeado director provisional da anexa de Oviedo, da que toma posesión en 1-IX-1950, e en 1967 accede ao Corpo de Directores Escolares de EGB. Permanece como director da citada escola anexa ata a data da súa xubilación, o 16 de novembro de 1982. Ao tempo que exerce como mestre, realiza a maior parte da carreira de Dereito na universidade de Santiago de Compostela e remata na de Oviedo, na que acabaría impartindo docencia de Historia do Dereito. Nesta cidade montou un bufete onde consultou e recibiu encargos relacionados coa súa función de letrado e tamén actuou como perito calígrafo.

Cando desempeñaba un destino militar en Intendencia en Lugo, en tempos da Guerra Civil, coñece a ovetense María Josefa Díaz-Vingolea Fernández, quen se trasladara con parte da familia á capital lucense para fuxir da zona de tensión centroasturiana. Casan en 1939 e desa unión nacen seis fillos. María Josefa, coa madre de Oviedo e o padre de Lugo, obtivo o título de Maxisterio, pero exerceu a profesión moi ocasionalmente. Unha vez falecida esta, Francisco acabará contraendo segundas nupcias con Atilana Leandra Milagros García Sánchez, natural das Figueiras.

Moi amante do fútbol, durante a súa xuventude participou como xogador en varios campeonatos do occidente asturiano ${ }^{5}$, unha área xeográfica da que estivo prendado e preocupado polos seus problemas, como ben declara nunha entrevista no n. ${ }^{\circ} 25$ d'El Faro de Tapia (7-I-1958). Francisco é herdeiro cultural da que el chamou «fulgurante década literaria del Eo» dos anos vinte (Fidalgo 1990) e do activismo desenvolvido arredor das Misións Pedagóxicas e da Biblioteca Popular Circulante de Castropol, institución que desempeñou un intenso labor nos campos musical e teatral (Suárez 2006b: 70-75). O noso autor

3 O descubrimento das actas e o poder consultalas debémosllo ao profesor Suso Fernández Acevedo.

4 Dos seus desprazamentos é doado atopar noticias na prensa local (El Aldeano, n. ${ }^{\circ}$ 91, 15 VII-1933; Las Riberas del Eo, n. ${ }^{\circ} 3040$, 9-IX-1933; n. ${ }^{\circ} 3093,15-I X-1934 ;$ n. $^{\circ} 3106,8$-XII-1934).

5 Na prensa comarcal encontramos referencias ao seu xogo (Las Riberas del Eo, n. ${ }^{\circ} 3090$, 25-V-1934). 
coñecía a tradición escrita da comarca e tamén a oral, da que foi un continuo observador. Como escritor, forma parte da xeración galegoasturiana de 1936 (Babarro 2007: 107-132), onde tamén figuran Alejandro Ramón Sela García (Vilavedelle, 1911 - Navia, 1982), Amador Fernández Mejeras (Ribadeo 19131971) e Ovidio Martínez Álvarez «Ovidio de Queipo» (Boal, 1915-1945). Trátase de autores nados na segunda década do século XX, moi activos na súa xuventude en actividades de carácter cultural, que ven a súa produción condicionada pola guerra e a situación política imposta pola Ditadura. O considerárense asturianos non impide que sintan os lazos lingüísticos e culturais que os unen con Galicia, un sentimento que se manifesta a través das relacións que manteñen con diferentes escritores e tamén intentando integrar as respectivas falas no galego literario da época ${ }^{6}$.

Ademais das incontables intervencións en eventos relacionados co maxisterio, como cursiños, homenaxes e actos oficiais diversos, Fidalgo é autor de múltiples traballos escritos e disertacións, dos que tan só enumeraremos unha mostra...

1936. «Un día cualquiera en Castropol. Inocentada» (Babarro 2007: 128-130).

1945. En Las Riberas del Eo, n. ${ }^{\circ} 3631$ (14-II), publica «El amor a la Patria»; onde destaca a vivencia da noitevella compostelá e a señardade pola terra asturiana.

1945. En Las Riberas del Eo, n. 3652 (14-VII), «Santiago: Fin de curso»; no que encontramos un retrato da Compostela dos anos corenta.

1945. En Las Riberas del Eo, n. 3657 (18-VIII), «Tierras de Padrón.- Herbón, San Antonio y su convento», un artigo onde salienta a descrición da romaría.

1948. En Las Riberas del Eo, n. ${ }^{\circ} 3820$ (5-X), escribe sobre a personalidade de «Gustavo Freire», con motivo do seu falecemento. Coidamos que tamén é da súa autoría o artigo da portada asinado por F. F. V., baixo o título «Del Eo, para el Miño. San Froilán», con motivo das festas lucenses.

1950. Publica en Lugo, na Tipografía de «La Voz de la Verdad», o libriño Prácticas de Enseñanza. Orientaciones.

1950. Versión mecanografada do poema «Nana pra dormir a os nenos».

1951. En marzo é premiado no concurso convocado pola biblioteca «Miguel G. Teijeiro» das Figueiras co tema Biografía literaria de D. Miguel G. Teijeiro, presentado con José P. Castro baixo o lema «Pueblo que honra a sus hijos, hónrase a sí mismo» ${ }^{7}$.

6 O seu posicionamento vén sendo unha manifestación do que certas veces se plasma como sentir colectivo: «En geografía, folklore, idioma, etc., etc., poco o nada nos diferenciamos de Galicia los asturianos occidentales, como poco o nada se diferencian de la Cantabria los asturianos orientales» («Desintegración», El Aldeano, n. $\left.{ }^{\circ} 89,15-\mathrm{VI}-1933\right)$.

7 Outorgado por unanimidade do xurado, o premio, de acordo coas bases, consistiu en 250 pesetas en metálico, «donado por la Junta de la Biblioteca», e un lote de libros polo mesmo valor, adxudicado polo Centro Coordinador de Bibliotecas de Asturias. Miguel García Teijeiro (Barres, 
1951. En Las Riberas del Eo, n. ${ }^{\circ} 3962$ (23-VI), escribe sobre a personalidade de «D. Fermín Bouza Brey» e reproduce algunhas das súas afirmacións en relación coas terras eonaviegas.

1954. En Las Riberas del Eo, n. ${ }^{\circ} 5033$ (2-X), «Divulgaciones. Arrendamientos rústicos según la Ley de 15 de julio de 1954».

1957. En Las Riberas del Eo de 28 de decembro, «De Figueras: haciendo historia. Inauguración de la torre del reloj y las Escuelas», onde recorda promotores, mecenas, obreiros e anécdotas relacionadas coa torre e coas escolas.

1958. En febreiro participa nun ciclo de conferencias organizado por Educación y Descanso no Hogar del Productor de Tapia de Casariego cos temas «la quinta provincia gallega y costumbres asturianas». O da quinta provincia no Occidente de Asturias abórdao tamén nunha entrevista que lle fan no n. ${ }^{\circ} 25$ d' $E l$ Faro de Tapia (7-I-1958).

1984. No n. ${ }^{\circ} 5$ d'El Mentidero de Tapia, p. 15, publica «Pequeñas historias de Barres», onde lembra unhas coplas que se cantaron polo tempo do Entroido, que recordaban a viaxe que realizaran á Roda as mozas da localidade, para ir ver un famoso predicador que actuara en Barres durante a Semana Santa de 1927.

1986. No n. ${ }^{\circ} 15$ d'El Mentidero de Tapia, p. 9, no espazo «A nosa fala. A fala d'aquí», publica unha serie de ditos e refráns, que continúa no n. ${ }^{\circ} 16$, p. 9.

No n. ${ }^{\circ} 16$, p. 11 , escribe sobre «El habla de Occidente». O autor lamenta o retroceso da «habla vernácula de occidente» e, «para ver si me entienden los jóvenes que me leen», remata o artigo redactando un pequeno texto na devandita fala...

Os veyos escrequeñados caron al sol y apeteirados xunto a figueira, algus fumaban y outros rilaban pan remolicado, esbatuxado nel prebe y na leite toyida que cheiraba a fermento y reloucaban de medo vindo a os rapacíos emporondados nua parede estarabouzando con berridos que esmendreyaba.

1987. No programa Figueras 87. Fiestas en honor de Ntra. Sra. del Carmen, «Pequenas historias dos mariñeiros del Eo» ${ }^{8} \mathrm{e}$ «El domingo de los sopapos en Barres -Pequeñas historias-».

1987. No programa das festas de Piñeira (Castropol) Fiestas de San Bartolo 1987, «San Bartolo de Piñera. A Festa das Peras y outras historias». O autor fala, en castelán, da chamada «Festa das peras urracas» e da súa relación coa romaría do santo para pasar na segunda parte a unha narración popular, «escrita na fala de aquí», sobre o personaxe de Antonón e San Bartolo, que é o fragmento que escolmaremos ${ }^{9}$.

Castropol, 1867-1936), membro da Real Academia Galega, da Academia da Historia e da Comisión de Monumentos de Lugo, levou a cabo diferentes investigacións de carácter arqueolóxico e histórico en Galicia e Asturias.

8 Co título «Pequenas hestorias dos mariñeiros del Eo» aparece en 1997 no n. ${ }^{\circ} 4$ de Entrambasauguas. A revista del Navia-Eo da Academia de la Llingua Asturiana.

9 Conservamos tamén un autógrafo, sen data, onde Fidalgo recolle crenzas relacionadas co santo. 
1987. No programa Ribadeo en Fiestas 1987, «Ribadeo y Camilo José Cela», recorda a estancia na vila, en 1952, de Cela, ao que Fidalgo consideraba amigo, que logo se verá reflectida en Del Miño al Bidasoa.

1988. No programa Festas da Patrona 88, «Un ayer y un hoy: El Puente de la Valiña-Porto y el de los Santos», recorda especialmente a inauguración do primeiro o 14 de agosto de 1863

1988. En xullo, no programa das Fiestas Patronales de Santiago Apóstol de Boal edita «Nana pra dormir os nenos», «Pequeñas historias de Boal: retablo dieciochesco. Linajes e hidalgos» e «Las adivinanzas del occidente asturiano» ${ }^{10}$.

1988. No programa das festas de Piñeira (Castropol), «El juego de brisca original de Antonón y outras cousas» ${ }^{11}$.

1988. No programa de festas das Figueiras (Castropol), «Pequeñas historias del Eo». Este mesmo texto reprodúcese no San Miguel 97 da Caridá baixo o título «Pequeñas historias del Eo na fala del pueblo».

1990. No programa Barres/90. Fiestas Patronales San Pedro Ecce Homo, «Origen de la lápida encontrada en la iglesia de Barres», «María Pastora. Pequeñas historias de Barres», «El Cuadro Artístico de Barres. Pequeñas historias» e «La rondalla y el teatro en Barres. Pequeñas historias».

1990. No programa Ribadeo. Festas da Patrona, «La fulgurante década literaria del Eo». O autor recorda a época de entre 1920 e 1930 e detense, especialmente, en tres obras: Recelo, do figueirense José Fernández Arias; Ribano$v a$, do ribadense Leopoldo Calvo Sotelo, e María, poema del Eo, do castropolense Pedro G. Arias.

1991. A través dunha carta (20-II-1991) comunicábame que estaba «preparando una $\mathrm{H}^{\mathrm{a}}{ }^{\mathrm{a}}$ de Figueras durante el siglo 20». Esta obriña, que non chegou a editarse, está actualmente en poder dunha das súas fillas. Noutra misiva (sen data) da mesma época tamén me informaba de que estaba «terminando un fascículo sobre 'la fala de Figueiras' recogiendo el vocabulario de esa zona que es numeroso y mucho perdido por no usarlo». Era constante a súa preocupación por elaborar un dicionario e, relacionado con el, conservamos varias notas léxicas, ademais das voces publicadas no libro de festas das Figueiras de 1997, en «Así falamos» de sites.google.com/site/pelamio.

1995. Pregón de las fiestas de la Virgen del Carmen y del Corpus, «Figueras, 9 de agosto de 1995». O autor lembra personaxes, costumes e anécdotas no vivir diario das Figueiras da súa nenez e xuventude.

\footnotetext{
10 Anota tamén que «pronto aparecerá un folleto titulado La guerra incivil de 1936 en Boal».

11 Aparece baixo o título «A brisca d'Antón y outras cousas» en 1998 no n. ${ }^{\circ} 8$ de Entrambasauguas. A revista del Navia-Eo da Academia de la Llingua Asturiana. O texto orixinal pode verse tamén en Babarro 2003 II: 267-270.
} 
1997. En abril participa en Oviedo nas I Jornadas Boalesas en el Centro Asturiano, organizadas en colaboración co Club Prensa Asturiana, coa conferencia «Boal, recuerdos y añoranzas» ${ }^{12}$.

1997. En Banda Municipal de Ribadeo. 5 aniversario 1992-1997, pp. 59-60, editado pola Asociación «Amadores da Música», colabora con «Amadores...», onde recorda anécdotas e personaxes, dos dous lados da ría, relacionados coa música.

\subsection{Poesía}

Unicamente lle coñecemos «Nana pra dormir os nenos», publicada en 1988 no programa Fiestas Patronales de Santiago Apóstol de Boal. O texto arranca dunha versión máis antiga que chegou a nós a través dunha copia a máquina, de 1950, asinada polo autor. O poeta parte dunha seguidilla popular, en castelán, para desenvolver unha glosa antitética, na que a oposición semántica se ve reforzada polo cambio de idioma e pola propia métrica, con estrofas de catro versos hexasílabos con rima asonante nos pares. Unha isometría que se rompe na estrofa cuarta (Mais, si te durmes) e na antepenúltima (Tou padre durme a cachos, / túa madre fai que durme). Esta antinana, inquietante, que nos recorda a «Canzón pra que un neno non durma» de Luís Pimentel (1981: 92), remata ao final cunha mensaxe de sosego.

$\mathrm{O}$ autor trata de acomodar o texto primitivo ás variantes fonéticas boalesas con formas como tollo, lleven, llume, etc. Ao lado destas, outras características que resaltan son o emprego vacilante das grafías «ll»e «y» en palabras que presentaban no latín os grupos LJ, C'L ou G'L (carballo, palleiro / oyos, teyado, paya), o uso de formas de plural como neníos, o artigo el, o posesivo tou e a copulativa $y$ en posición preconsonántica. Estes trazos circunscriben o texto ao sistema lingüístico propio da área dialectal B, que comprende varios concellos asturianos e o lucense de Negueira de Muñiz (Babarro 2003: 531), circunstancia que non impide que o autor faga algunha concesión a formas máis occidentais, como é o caso de canto. Por outro lado, chaman a atención castelanismos como engañar, hadas, lluvias, buenos..., que, sen dúbida, debemos atribuír, igual que certas variantes coloquiais, á ausencia dunha normativa escrita que actuara como referente.

\subsection{Narrativa}

O conxunto está constituído por textos entroncados coa narrativa popular comarcal que desenvolven anécdotas e tradicións cunha base de humor e que teñen como protagonistas personaxes temporalmente próximos ou recollidos da

12 Idoya Rozón informaba en La Nueva España de 12 de abril, que «Villaveirán, con un acento más gallego que asturiano, entretuvo al público asistente al acto con sus recuerdos sobre Boal, que arrancan en 1933». 
transmisión oral. «Pequenas historias dos mariñeiros del Eo»e «Pequeñas historias del Eo» manteñen As Figueiras como lugar referencial; mentres que [«Chamábanye Antonón»] (segunda parte de «San Bartolo de Piñera. A Festa das Peras y outras historias») e «El juego de brisca original de Antonón i outras cousas», ten como lugar a Piñeira de Castropol. O termo pequenas historias acabou sendo utilizado por Fidalgo para establecer unha fórmula literaria que lle permitía rememorar periodicamente os recordos de xuventude. Debido ao seu interese, pola intencionalidade literaria do autor, aínda que relatada en castelán, quixemos editar no mesmo grupo «A noite da garfella», localizada en terras de Boal, da que dispoñemos dunha copia impresa, sen ano nin lugar de edición, que seguramente foi tirada dunha obra colectiva. Sabemos por María Antonia Fidalgo que o seu padre participara con esta narración nun concurso literario. Pola dedicatoria que o autor introduce na cabeceira, quizais debamos pensar que a primeira versión remonta á súa etapa boalesa; xa que logo, sería de arredor de 1940.

En canto á lingua utilizada, moi deturpada por mor do castelán, o autor proponse escribir «na fala de aquí», que vén sendo a que consideramos como subárea dialectal B1, dado que non existe palatalización en voces como elos, lougo, toleiría, etc. Tamén poderiamos considerar baixo a mesma intencionalidade a grafía «y» en palabras como veya, oyo, moyaba, coyer, meyor, tayolo, apareyou$y e$, etc. Outros fenómenos que se corresponden con esta zona dialectal son o mantemento do - $\mathrm{L}$ - intervocálico en palabras como calentes, delante...; o artigo el (coas contraccións al, del...); o numeral ou indefinido úa (con algúa, ningúa...); os imperfectos vía «viña», tía «tiña»..., e os perfectos fortes como trouxiche. Xa con maior extensión xeográfica, por caracterizaren as falas galegas orientais, están os plurais do tipo diversiois e as formas verbais fais, fain e tein. Por outra banda, o intento de reproducir a coloquialidade e a falta de hábito no uso dun sistema escrito unificado favorece o emprego de abundantes alternancias: us úos, mau mao, -eu -eo e -iu -ío (atreveu, meteulo, viu, oíu / debeo, recibíolo, vío, ouío oío, vivío...), e $\sim$, nun sei non sei, pra pa, pos pois, cuando cando, etc. Aos condicionantes anteriores habería que engadir a presenza do castelán no medio social en que se desenvolvía o autor así como na súa comunición escrita habitual, que abrirá a porta a unha rea de castelanismos: a la funerala, a los viaxeiros, a sangue, ágil, aunque, ayer, bueno, carcajadas, Cielo, corriente, cosa, creínla, cuchillo, cucliyas, cuenta, diecisiete, descuajaringado, dos ( dous), encontrarla, hazaña, Infierno, juerga, juez, jugar, la mar de, manera, mientras ( mentras), ocho, oyentes, pañuelo, prisa, pruebas, replicó, sacudirlos, sollozos, su ( súa), tener, una ( úa), veían ( vían), vino, xuego, etc.

Tato Fontaíña (2006: 105) mantén que o teatro galego do século XIX e precedentes formaba parte da tradición oral popular e «tiña como fin último ou ben divertir ou ben adoutrinar» e que «a intención dos seus autores non era en absoluto a de facer literatura e moito menos a de que as súas pezas ultrapasasen o tempo da función para a que foran escritas». Algo similar debemos pensar para moitos destes escritos ocasionais de autores galegoasturianos, que, aínda sentíndose transmisores da cultura local, non sempre eran conscientes de estar elabo- 
rando unha lingua literaria, que debería mirar ás esencias e evitar deturpacións causadas pola lingua de máis prestixio.

\subsection{Teatro}

Así como a poesía e as narracións de Fidalgo foron citadas e mesmo alcanzaron certa difusión (Babarro 2003, Vol. II: 267-271 e 2007: 126-132, Fernández Acevedo 2008: 76-77, Frías 2003: 49 e Suárez 2006a: 116-118), o que ten permanecido máis no esquecemento é a súa musa dramática, non só no que toca á difusión escrita, senón tamén á dimensión escénica. Contemplado desde As Figueiras, o seu teatro recolle, por dicilo dalgún xeito, o facho de Arias Campoamor, quen estreara na localidade castropolense, a noite de Reis de 1926, o esbozo de comedia en dous actos El trato. Ao mesmo tempo, é continuador da actividade teatral desenvolvida polos animadores da Biblioteca Popular Circulante (Suárez 2009), coa que coidamos garda unha estreita relación. Moita máis da que podería manter con Cousas d'outro tempo. Condo el cariño é de verdá, creada e representada en 1936 pola Agrupación Artística de Armal, que coincide coa etapa boalesa de Paco.

Son varios os elementos que nos falan do compromiso do autor coa cultura escénica. Así, o dez de maio de 1934 encontrámolo de apuntador no «Teatro de Figueras» co «Cuadro Artístico Atalaya» nas comedias Ramo de locura de Joaquín e Serafín Álvarez Quintero e Parada y fonda de Vital Aza. Sabiamos, ademais, do seu gusto polas marionetas e de que fomentou este elemento lúdico no seo familiar para a educación dos propios fillos. Tamén tiñamos noticia de que, ao tempo que desempañaba a función docente foron varias as escenificacións organizadas por el. A isto habería que sumar que nos seus escritos figuran abundantes datos sobre o mundo teatral, coma o que nos informa do Cuadro Artístico de Barres ou aqueloutro («Amadores...») que nos descobre que en 1935 actuou de cronista para La Comarca de Ribadeo informando sobre a escenificación dunha zarzuela por mozos e mozas ribadenses no Teatro Helenias de Boal.

Como xa apuntamos en 2007, un folio mecanografado referido a unha foto, que se conservou entre os seus documentos, informa que en 1941 un grupo de alumnos da escola graduada de Boal, localidade coa que continuou mantendo lazos afectivos ao longo dos anos e colaborando nos seus programas de festas, representara unha peza súa. Nese escrito menciónase como «juguete cómico»e dáselle o título de Las dos riquezas. Orlando Fernández, un dos nenos actores, lembra, en 2012, que se trataba dunha escenificación de «ricos» e «pobres». Nela aparecía a figura do «Americano» contrastada con tipos do país, un contraste que se aprecia tamén a través da caracterización dos actores que figuran na referida foto. Este xoguete cómico, como actividade dentro da escola de nenos, unicamente contaba con personaxes masculinos, que desempeñaban o papel de pais, fillos, veciños, etc. O autor conservou tamén outra foto, dun grupo formado por mestras e autoridades, cunha anotación no reverso que a data en 1942 e que aclara que foi «sacada el 23 de Abril con motivo de la fiesta del libro celebrada en la Graduada en donde se puso en escena un sainete de mi creación». Non sabemos se se trata do título mencionado do ano anterior ou se é 
unha peza diferente. Cabe incluso a posibilidade de que unha das datas estea equivocada e se refiran as dúas á mesma escenificación.

En datas máis próximas, Everardo Fernández (2008: 166-167) reproduce tres páxinas dunha obriña que lle regalara Fidalgo, da cal me fai chegar unha copia completa; copia que difundimos entre familiares e coñecidos para celebrar o centenario do nacemento do autor. Do texto, que é o que aquí ofrecemos de novo, non coñecemos o título, xa que o caderniño mecanografado carece, actualmente, de cabeceira. Trátase dun sainete de trama sinxela. Juanita ( Juana, Xuana), moza de Antón, empuxada polos consellos de Pepa, súa nai, déixase engaiolar nos afagos e as aparentes riquezas de Bonifacio, veciño que acaba de chegar de Buenos Aires con moita fachenda. A comicidade da representación conséguese, en parte, contrastando as «gringuadas» do personaxe que fala con acento porteño coas «gallegadas» de Antón, o verdadeiro namorado de Xuana, e complétase coas consecuencias da borracheira de Isidro, home de Pepa e pai de Xuana, que acaba ordenando a formalización ante a Igrexa da relación entre Xuana e Antón, ao tempo que promete non volver nunca máis á taberna.

Sen contarmos co texto da escenificación escolar, non podemos saber a relación plena que existiría entre ambas as dúas. En principio, vemos que o número de nenos actores non coincide cos personaxes do orixinal conservado por Everardo. E tampouco o reparto de papeis que figura no caderniño parece ter que ver con xentes de Boal. A pesar de todo, unha vez observado o tema da última e relacionándoo co título daquela, ademais de considerar que nas dúas aparece o personaxe do «Americano» contrastado con tipos do país, podemos imaxinar, cando menos, certo paralelismo. E, subindo un chanzo máis, pensarmos que o xoguete boalés fora unha mera adaptación escolar do noso sainete, acomodada ós condicionantes de actores, público e mesmo momento histórico. No medio deses condicionantes puido encontrarse a mesma lingua. Hoxe en día non sabemos con certeza en que idioma se desenvolveu a representación de Boal. Orlando, asegura que a fixeron en castelán, que, segundo el, era o único que se empregaba na escola. Pola contra, Teodosio Sáenz, tamén en agosto de 1912, despois de dubidar, contéstame «y sería en bable, que es lo que allí entendía la gente». Pensando que na década de 1940, cando o galego escrito pasaba por unha época de escuridade por mor da situación sociopolítica, Sela, Mejeras e Queipo, amigos e compañeiros de xeración, seguían colaborando esporadicamente en galego en Las Riberas del Eo, e considerando que a oposición galego / castelán xoga un papel decisivo na caracterización dos personaxes e na transmisión da mensaxe, é posible que Fidalgo mantivera a lingua orixinaria na representación escolar do seu sainete.

Partindo de todos estes factores, non resultaría demasiado arriscado restaurar a cabeceira da obra co idioma que ensalzan os propios personaxes e, deste xeito, asignarlle ao orixinal conservado o título de As dúas riquezas. Por un lado, a verdadeira riqueza do que se manifesta cun trato natural empregando a lingua do país, cun cariño sincero e conservando os valores tradicionais, fronte á riqueza daqueloutro que muda de estatus económico e pasa a expresarse nun idioma foráneo, adopta modais postizos e simula esquecer as súas orixes. No teatro popular costumista do tempo das Irmandades, ben diferente daquel de 
carácter culto elaborado durante a mencionada «fulgurante década literaria del Eo» polo veiguense Armando Cotarelo Valledor (Trebón, 1922; Sinxebra, 1923; Lubicán, 1924; Hostia, 1926; Beiramar, 1931...), é moi habitual o personaxe do americano que regresa falando en castelán (non sempre en actitude desprezativa de cara ao idioma do país). Véxanse, a modo de exemplo, Mal de moitos (1915) de E. Charlón Arias e M. Sánchez Hermida (Lourenzo + Pillado 1982: 111123), Almas mortas (1922) de Antón Villar Ponte, Todo ten goberno (en Monifates, 1928) de Xavier Prado «Lameiro» e, no occidente asturiano, Xan Cabrito de Manolo e Paco Marinero (Suárez 2009: 216-265) e, xa en tempos máis próximos, Vénnos el americano de Manuel García «Galano» (1993: 257-300).

A valoración do mundo tradicional campesiño e do propio fronte ao alleo, herdados do século XIX (Ogando 2006: 79), que se fai tan característico das Irmandades da Fala, emparenta o noso sainete co «teatro aldeano» da xa citada Biblioteca Popular Circulante (Bugallo 2009: 25-27 e Suárez 1999: 61). Tendo en conta isto, aínda que, polo de agora, non dispoñamos de elementos suficientes para demostralo, dános a impresión de que a peciña de Fidalgo remonta á primeira metade da década dos trinta. Mesmo non sería nada estraño que o autor, de valorarmos certos paralelismos entre as dúas obras (Abuín + Ruibal 2006: 23-24), se vira influenciado de cerca pola comedia $O$ pazo de Manuel Lugrís Freire, que fora representada polo coro ribadense Cantigas d'a Mariña o día de San Pedro de 1933 no Casino-Teatro castropolense ${ }^{13}$.

Se, observando as narracións de Fidalgo, descubrimos que están plenamente integradas na tradición local, co sainete ocórrenos outro tanto. As cántigas que o autor pon en boca de Antón e Isidro son boa mostra da cultura tradicional. Mais, o uso de trazos populares non impide a utilización doutros de procedencia culta como poden ser os tangos que canta Bonifacio e os fragmentos tomados de Zorrilla, Rubén Darío e Valle-Inclán.

A conservación do orixinal é deficiente. A pesar diso, non resulta difícil restaurar as ausencias; cando menos, para aproximármonos á versión do autor. $\mathrm{O}$ texto ofrece varias correccións manuscritas e as intervencións dos personaxes encontrámolas sempre suliñadas á man, salvo nas dúas últimas páxinas. O aspecto actual destas dúas, que rexistran tamén formas lingüísticas que contrastan, en certo modo, coas do resto da obra, pódenos levar a deducir que foron escritas nun momento diferente, cunha cinta gastada, cun papel de calco, cunha máquina de impresión menos nítida ou, simplemente, que a humidade e o tempo foron esvaendo a impresión. Considerando todos estes elementos, mesmo

13 «Se presentó una comedia gallega titulada «O Pazo» que, aunque pecase de cierto amaneramiento teatral, contenía alusiones que fueron celebradas por una parte del público y acogidas con no tanta algazara por otra parte: se trataba de un americanín joven y rico que desdeñaba las habilidades madrileñoides de una jovencita pizpireta, por los atractivos más ingenuos de una rapaza «enxebre». En tercer lugar, el Coro interpretó varias canciones de compositores gallegos del siglo pasado -en su mayor parte glosando versos de Rosalía-, entre las que iba una original del director del Coro. Para remate, se cantó el Himno Gallego, que fue escuchado de pie, como obligada cortesía a nuestros vecinos (y con más emoción, por algunos «irredentos» simpatizantes)» (El Aldeano, n. ${ }^{\circ}$ 91, 15-VII-1933). 
chegamos a pensar que puideron ser aproveitadas dunha versión anterior redactada con variantes dialectais diferentes.

Desde o punto de vista lingüístico, un dos trazos que a singulariza é o emprego de formas como alló, tolluras, llume, llougo, oíllo, etc., polo cal cabe imaxinar que puido ser creada para representar na zona en que se palataliza o L- inicial e o-LL-intervocálico latinos ou, simplemente, que o autor utilizou o sistema que lle resultaba máis entrañable, por ser o da súa familia. A obra caracterízase, ademais, como ocorre noutros textos do autor, polo emprego (non sistemático) do grafema «y» en voces como ye, muyer, fiya, trabayador, tayada, etc. A pesar das dúas características mencionadas, dista moito de ofrecer un sistema lingüístico unificado que puider responder completamente á área devandita. Velaquí, ademais das xa anotadas, outras voces que responden a diferentes variantes dialectais da zona, convivindo moitas delas con outras opcións: muito, escuita ( moi); pos, despós ( pois, despois); condo cuando; baxa; búas ( boas); chíos; úa, ningúa; calente, meiroleiros, adelante ( diante); -ois ( -ós; perrois / Naciós); el, lo ( o); eo ( eu); pronomes átonos lo, la ( na; nun la ltena); estos, esos; tou, sou; mía ( miña), tía «tiña» (/galiña); dice, dicen; fer ( facer); peizme ( paréceme); puer ( poñer, poñerás); quer ( quere); veo, vío ( viu); -ais ( -ades, -edes; embobais, chamais / tades, queredes); teis ( tes), tein; tuviche; $i(\sim e)$; pro ( pero), pra pa ( para); nun ( non), unde, hoi, e algunhas máis.

Como xa se observou nas narracións, o uso de formas coloquiais dá paso a castelanismos que actualmente resultarían insólitos nun rexistro coidado, tales como relojes, jumento, fijate, oro, cosa ( cousa), aprovechar, buenas ( boas, búas), cuenta, suena, acompañamiento, etc. Ou formas híbridas como vamos a ter, vai a morrer, diecioito, etc. Así mesmo, o castelán, igual que nos primeiros tempos da nosa literatura decimonónica, tamén é a lingua dos acoutamentos escénicos. A pesar de todo, esta obra de xuventude, desde o punto de vista lingüístico, parece máis coidada que a narrativa, elaborada nunha época na que o autor xa non mantiña un contacto diario coa lingua.

A acomodación da obra á fala comarcal, como vemos, non impide o emprego de formas galegas foráneas. Sorprende o uso do diminutivo en -iño -iña (Bonifaciño, Pepiña; non en -ín -ía, como cabería esperar), utilizado polo matrimonio de Pepa e Isidro. Estes dous personaxes tamén din galiña e miña, variantes que aparecen na penúltima páxina. Tanto nesta, como na seguinte, rexístranse outras formas (Naciós, tena, facer, o mismo, o domingo, diante, boas, non volvo, $e$, diante, moi...) que nos fan pensar que o texto das dúas foi aproveitado, como xa adiantamos, dunha versión anterior que, sen renunciar ao comarcal, quizais se acomodara máis, no seu conxunto, ao galego literario da época. Tanto que existira esa primitiva versión como que non, a integración do particular no universal debemos contemplala cos ollos dos escritores mozos da Xeración de 1936; pois é un criterio que manteñen tamén «Ovidio de Queipo» e Mejeras, con quen Paco mantivo amizade durante toda a súa vida. Os tres, sen renunciaren á súa asturianidade afectiva e administrativa, séntense dentro dunha colectividade lingüística na que o Eo servía de ponte e non de muro xebrador. A súa actitude non difería, polo tanto, da doutros autores de Galicia, que conxuga- 
ban as formas que lles chegaban a través de textos literarios coas comarcais, especialmente se querían plasmar a fala popular ${ }^{14}$.

No plano ortográfico salienta tamén o uso do apóstrofo en formas como d'América, cu'a escasez, qu'a xente, xa m'entendes, tuvo n'América e algunha máis; por ser un trazo que non temos constatado nos escritos de Fidalgo de a partir dos anos cincuenta. A supresión do apóstrofo, xa contemplada nas normas para a unificación do idioma elaboradas en 1933 polo Seminario de Estudos Galegos, caracterizará, a partir de 1950, as publicacións da editorial Galaxia. Non sabemos se Fidalgo, lector de Cunqueiro e doutros escritores coetáneos, acabou incorporando aos seus escritos de posguerra a innovación ortográfica por influencia das súas lecturas ou se máis ben se debe a unha opción individual independente de calquera normativa, onde o autor opta maioritariamente por unha segmentación de carácter analítico na que as diferentes categorías gramaticais manteñen a forma plena.

\subsection{A presente edición}

Tratamos de ser fieis aos textos orixinais, incluíndo os castelanismos e as vacilacións dialectais que rexistran. A pesar diso, introdúcese, para facilitar a lectura, algunha variación na puntuación e nos tipos de letra, ademais de pasarmos por alto, nos escritos a máquina, os erros mecanográficos facilmente identificables. Así mesmo, incorporamos como opción preferente, aínda que o indiquemos a pé de páxina, todas as anotacións manuscritas do autor.

O criterio de acentuación gráfica, con certa anarquía nos orixinais, e o uso de grafías como «b», «V», «h»e «X Academia Galega. Desta maneira, tú, tí, mín; chubisca; nunbos; ;ay bay o!, xa hora, ;(h)ay e o!; extrañar.., transcríbense como tu, ti, min; chuvisca; nun vos; ¡ai, vai, ho!, xaora, ;ai é, ho!; estrañar... No verbo (es)tar mantemos o til nas aféreses tá, tás, tán e té. A actualización afecta igualmente á grafía e segmentación de contraccións e crases como a os, cu'a escasez, as coba, arrastro, etc., que pasan a aos, cua escasez, a escoba, a rastro, etc.; de aí que os contados casos de apóstrofo que figuran no sainete tamén se transcriban de acordo coa ortografía actual. Así d'América, n'América, d'outros... pasan a de América, na América, doutros... Fronte a estas actualizacións, respectamos a grafía que resalta o seseo de Bonifacio, en formas como prinsesa, amigaso, castiso, conose, lus, esclavitús, etc.

A copulativa $y$ representámola por $i$ e, seguindo a mesma norma, formas como contey, rey, ay, foy, muy, hay, allindarey; mayor, oyes, vaya, etc., pasan a contei, rei, ai, foi, mui, hai, allindarei; maior, oies, vaia, etc. Este criterio, en cambio, non se fai extensivo ás palabras que derivan dun étimo con $\mathrm{LJ}, \mathrm{C}^{\prime} \mathrm{L}$, T'L ou G'L. Nestes casos, a grafía «y» (que a miúdo é sentida como un diferen-

14 Así, en Contos de polavila de José María López encontramos caseríu, tíu, fíu; curenta, fulgueira; unde, nunde; muito, mui, escuitar; eo, pareceo, convenceo, morreo; deixache, viche, comprache; tábache; Manuelín, Tomasín; pra, pro, e outras moitas. 
cialismo asturiano fronte ao galego normativo) responde a unha evolución fonética do propio sistema lingüístico que para un reducido número de falantes conservadores do baixo Navia posúe valor fonolóxico en parellas como esfoyar / esfollar, gayo / gallo, etc. O que se rexistre unha ampla zona e sistemas persoais con confluencia das dúas solucións (ben con lleísmo, ben con ieísmo) está na causa da vacilación gráfica de Fidalgo. $\mathrm{O}$ escaso rendemento fonolóxico deste a miúdo chamado «yeísmo histórico» non impediría, tal como se fixo en catalán, unificar con «ll» a ortografía das dúas solucións; non só por pensar nas áreas occidentais do Principado que manteñen a pronuncia da palatal lateral (esfollar / esfolar, gallo / galo...), senón tamén por considerar a funcionalidade de acomodarse á ortografía do resto do galego. A pesar diso, nesta edición, reproducimos fielmente as vacilacións do autor (ye, muyer, fiya, trabayador, tayada, paya; centeya... / lle, decíalle, palleiro; centellazo...).

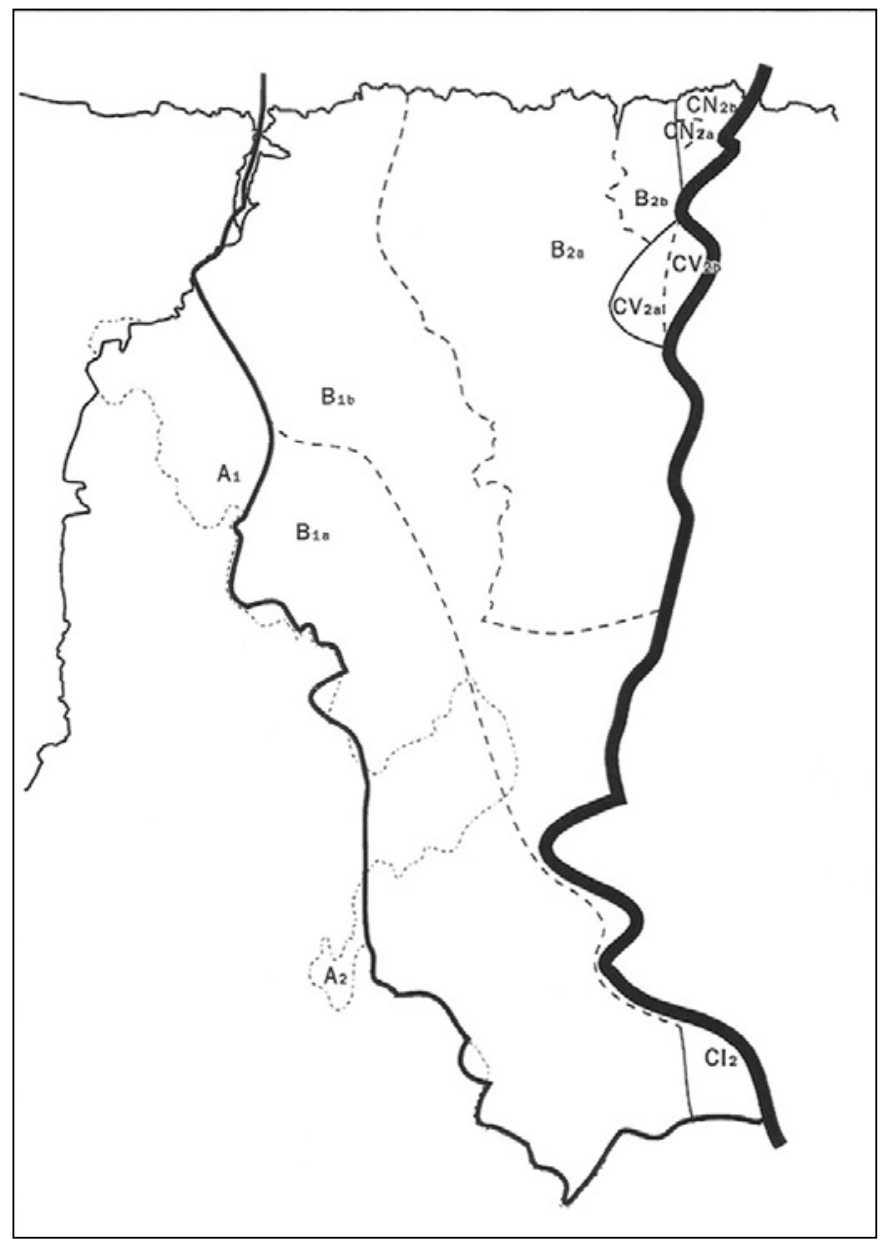

Áreas dialectais do galego en Asturias e leste de Lugo. A obra de Fidalgo, enmarcada, con trazos dialectais da área B, participa tamén de características da A e de formas propias do galego común. 


\section{EDICIÓN DA OBRA}

\subsection{Nana pra dormir $0 \mathrm{~s}^{15}$ nenos}

Duérmete, nenito, que viene el coco a llevarse a los niños que duermen poco.

Nun ${ }^{16}$ durmas, nenín ${ }^{17}$, nin peches os oyos ${ }^{18}$ que $\mathrm{el}^{19}$ coco $\mathrm{i}$ as bruxas levan solo aos tollos ${ }^{20}$.

Nun temas al coco, ás bruxas i al demo, que eso ${ }^{21}$ sonche bromas pra $^{22}$ engañar ${ }^{23}$ aos nenos.

Nun durmas, pequeno, berra canto ${ }^{24}$ poidas, espernexa $i^{25}$ grita i, si ${ }^{26}$ queres, chora.

15 En 1950, a os. Dámoslle prioridade á edición de Boal, de 1988, por ser a última.

16 Variante fonética de non átono, tamén reflectido no penúltimo verso (non lleva).

17 A terminación -in, en lugar de -iño, ademais de empregarse en Asturias e no Bierzo, caracteriza unha ampla zona da provincia de Lugo (Santamarina 1982: 177), onde algúns autores a seguen utilizando ao lado da forma maioritaria (Núñez 2005: platadín, Pepín, instantín...).

18 Neste tipo de voces o autor vacila entre as grafías «y» e «ll» (oyos, teyado, paya / carballos, palleiro). Entre os actuais escritores asturianos encontramos un grupo que opta pola ortografía diferencial, potenciada polas normas ortográficas da Academia de la Llingua Asturiana, e outros que manteñen o «ll», ben por conservaren no sistema familiar a articulación da palatal lateral, ben por empregaren a ortografía do resto de Galicia (Álvarez 1995, Calvín 2013, Frías 1991, García Rivas 2007, Quique Roxíos 2002).

19 Forma do artigo que caracteriza parte das falas galegoasturianas.

20 En 1950, tolos. O autor procura acomodar este tipo de voces á fonética da área de palatalización (tollos, lleven, llume, lleva / ladra, levan).

21 Var. maioritaria do galego oral, xunto con esto e aquelo (fronte ás normativas actuais isto, iso e aquilo), moi empregada na literatura dos séculos XIX e XX.

22 Forma coloquial, en lugar de para, moi utilizada na literatura.

23 Castelanismo, por enganar.

24 Forma do galego normativo presente tamén no Principado ao lado das variantes condo e cuando.

25 Var. da copulativa $e$. Así como en posición prevocálica o uso de $i$ caracteriza unha grande parte da xeografía galega, en situación preconsonántica o seu emprego tense espallado na oralidade dos últimos tempos por presión do castelán. Os textos galegoasturianos de principios do XX xa rexistran este cambio.

26 Cast., por $s e$. 
Mais, si te durmes ${ }^{27}$, meu neno pequeno, pode que te lleven ${ }^{28}$. as hadas ${ }^{29} \mathrm{o}^{30} \mathrm{el}$ demo.

A noite ${ }^{31}$ tá $^{32}$ moura, ximben $^{33}$ os carballos, el vento i a lluvia ${ }^{34}$ turran $^{35}$ nel $^{36}$ teyado.

Tou ${ }^{37}$ padre durme a cachos, túa madre fai que durme, el can ladra ás sombras, chuvisca no llume ${ }^{38}$.

El vento ${ }^{39}$ rebinca $^{40}$ por entre el palleiro, xoga con a paya, ¡chegou el inverno!

Nun durmas con medo, meu neno pequeno, que el demo non lleva ${ }^{41}$ aos neníos ${ }^{42}$ buenos $^{43}$.

$27 \mathrm{O}$ autor utiliza aquí durmes e durme, alternativa oral das normativas dormes e dorme. Esta última aparece no sainete.

28 En 1950, leven.

29 Cast., en lugar de fadas ou equivalentes.

30 Cast., por ou.

31 Nos dous orixinais, noita.

32 Aférese de está moi empregada na oralidade. Aínda que na comunicación literaria predominen as formas plenas, en obras que reflicten a fala coloquial podemos rexistrar tamén as reducidas (Antoloxía 2013: 19, 25, 27...).

33 Quizais un cruzamento entre cimbran «móvense» e ximen. En 1950, ximen.

34 Cast., por chuvia.

35 Baten con insistencia.

$36 \mathrm{O}$ autor utiliza a forma innovadora, de caracter analóxico, e tamén a conservadora (nel teyado / no llume).

37 Fidalgo, igual que outros escritores de Asturias e León (Poncelas 1995: 106), emprega os posesivos etimolóxicos $\operatorname{meu}(s)$, $\operatorname{tou}(s)$, sou(s); fronte ao maioritario sistema analóxico $(\mathrm{meu}(\mathrm{s})$, $\operatorname{teu}(s)$, seu(s)) utilizado no resto de Galicia, se descontamos algunha transcrición da oralidade do occidente coruñés onde se mantén tamén o primeiro.

38 En 1950, lume.

39 En 1950, esta palabra parece sobreimpresa sobre trasgo.

40 Rebrinca, enreda.

41 No orixinal, nonlleva.

42 Var. da área asturnegueiresa, caracterizada pola correspondencia -in - -íos, nenín - neníos (fronte aos sistemas nenín - neniños e neniño - neniños). O autor usa tamén vicíos, escarpíos, etc.

43 Cast., por bos. En 1950, que el demo escapa / dos neníos que son buenos. 


\subsection{Pequenas historias dos mariñeiros del $\mathrm{Eo}^{44}$}

Ricardo andaba al barcaxe ${ }^{45}$ i pasaba el día levando i traendo a xente nel bote desde as Figueiras a Ribadeo i volta outra vez. Bueno ${ }^{46}$, esto é un decir, porque os viaxes $^{47}$ eran poucos i a competencia muita ${ }^{48} \mathrm{i}$ además ${ }^{49}$ el amo del bote i el iban ${ }^{50}$ a medias i os dous reales ${ }^{51}$ que cobraban por persona ${ }^{52}$ daba pouco pra repartir.

Por eso tía ${ }^{53}$ que esperar que se xuntasen dous ou tres viaxeiros. Úa ${ }^{54}$ mañá chegou úa veya ${ }^{55}$ con muito remango pedindo que $1 a^{56}$ levase a Ribadeo, que tía muita prisa ${ }^{57}$.

—Ai, señora, ten que esperar a que veña algúa persona más ${ }^{58}$; porque, si la levo a $\mathrm{Vd} .{ }^{59}$ sola, teño que cobrarye como si foran dúas ou tres, posto que por dous reales nun podo fer $^{60}$ el viaxe.

- ¿Pois tu ${ }^{61}$ sabes quen son eu? -replicó ${ }^{62} a^{63}$ veya, con muito retintín.

—Non, señora, nun sei que é Vd.

44 Partimos da edición das Figueiras de 1987, que nos proporcionou o autor en 1991 con algunha corrección manuscrita (entre elas, o propio apelido, que figuraba como Villaselán), e tamén a versión mecanografada enviada á imprenta.

45 Cast., por á barcaxe.

46 Cast., por ben.

47 Cast., por as viaxes.

48 Var., de moita, rexistrada en falas do bloque oriental e occidental (Fernández Rei 1990: 50). Do mesmo xeito, mui e escuita. A presenza do ditongo ui na literatura salienta dun xeito especial na poesía pondaliana. Recentemente, Lema Suárez (2013) utiliza as formas con ui para caracterizar a xentes do noroeste da Coruña.

49 Cast., por ademais. Cabería pensar tamén nunha correspondencia do tipo despois - despós.

50 Var. de ían.

51 Aínda que no occidente do Principado tamén rexistremos os plurais do tipo reás e reais, un trazo característico das falas galegas de Asturias, parte de Lugo e León (Seco 2004: 435) é o mantemento do -L-intervocálico latino. Iso explica que Fidalgo utilice formas como reales, solo, meiroleiro, salir, palo, cul, calente, molín, etc.

52 Cast., por persoa.

53 O autor emprega as variantes asturnegueiresas tía e vía en lugar de tiña e viña.

54 Var. de unha propia de falas orientais. Do mesmo xeito, máis abaixo, algúa por algunha. Nos actuais escritores galegoasturianos rexístranse as dúas variantes (Rico 2012, García-Galano 2010).

$55 \mathrm{O}$ autor, nesta narración, transcribe con «y», e non con «ll», veya, ye (s), fiyo, oyo, moyaba, ya, coyendo, meyor e o castelanismo cucliyas.

56 Var., en lugar de $a$, moi potenciada pola presenza do castelán.

57 Cast., por présa.

58 Cast. Repárese en que o autor usa tamén a forma galega, máis.

59 Cast., por Vde., vostede.

60 Var., por facer, dalgunhas falas galegoasturianas e galegoestremeñas (Costas 2013: 164).

De aí, máis adiante, fía por facía e fendo por facendo.

${ }_{61}$ Forma etimolóxica (en lugar da normativa $t i$ ) propia das falas orientais e meridionais (Fernández Rei 1990: 75), amplamente documentada na literatura (Noriega 1982: 127, Santiago 1961: 114, Vidal 1920: 44).

62 Cast., por replicou.

63 Corrección manuscrita do autor sobre un la impreso. Na versión a máquina, replicó la veya. 
—Pois soi ${ }^{64}$ a madre del cura de Barres.

Ricardo calou us ${ }^{65}$ segundos; mas, aquela soberbia da veya, atragantóuseye de tal maneira, que, nun podendo máis, díxoye:

- ¿I Ud. ${ }^{66}$ sabe quen soi eu?

$-\mathrm{Pos}^{67}$ non; nin me fai falta.

—Pois, pra que lo sepa ${ }^{68}$, soi fiyo de Don Sabino, el cura de Tapia.

Ricardo quedou a gusto como si soltara un sapo del gorgoleiro ${ }^{69}$ i botouye úa sonrisa ${ }^{70}$ de satisfación mirando pra a veya, a que, con cara de pasmada, nun ye quitaba oyo $\sin ^{71}$ atreverse a gurgutar, chegando así a Ribadeo sin falar úa palabra. Detrás de Ricardo chegou al pouco tempo, noutro bote, el compañeiro de oficio, Leonardo, traendo dos ${ }^{72}$ viaxeiros más. Había un pouco mar de fondo xunto a un nordeste que fai bailar aos botes. Nel muelle ${ }^{73}$ el mar subía i baxaba $^{74}$ más da cuenta ${ }^{75}$, i Ricardo, más delgado i ágil ${ }^{76}$, axudou a desembarcar a $\operatorname{los}^{77}$ viaxeiros dos dous botes, dándoyes a mau ${ }^{78}$ desde el muelle.

—Veña, salta, vamos tomar us cha[n]queiros ${ }^{79}$-invitou Ricardo.

Leonardo, gordo i torpe, tuvo ${ }^{80}$ un tempo esperando que el mar subise pra saltar a terra; amagaba i nun daba i as olas subían i baxaban. Cando ${ }^{81}$ por fin lo fixo, xa era tarde i quedou agarrado colgando del cabo del risón ${ }^{82}$.

El mar moyábaye as pernas i as maus nun aguantaban el peso del corpo. Entrouye el medo de caier ${ }^{83}$ al fondo i, chorando aterrado, berraba:

Cast. Contrástese coa forma son da intervención anterior da mesma persoa.

65 Variante centrooriental, equivalente a uns. O autor alterna esta forma con úos.

66 Cast., por Vde., vostede. Na copia a máquina figura $V d$.

67 Obsérvese a altarnancia entre pois e pos. Esta vacilación podemos achala en autores que reflicten a fala popular doutras áreas (López Lajas 1998: 28-29).

68 Cast., por saiba.

69 Gorxa, gola.

70 Cast., por sorriso.

71 Cast., por sen.

72 Cas., por dous. Na copia a máquina, dos.

73 Cast., por molle, peirao, embarcadoiro...

74 Forma conservadora do galego oriental, fronte á innovadora baixaban (Santamarina 1982:

177). Esta última, tamén rexistrada no Principado, é usada por algúns escritores galegoasturianos (Rivas 2009).

75 Cast., por conta.

76 Cast., por áxil.

77 Cast., por os. Tamén na copia a máquina.

78 Variante centrooriental, en lugar da occidental man. O autor vacila entre as grafías mau e mao. Entre os moitos autores que rexistran esta variante dialectal figuran Curros (1880: 115) e Lamas (1981: 13).

79 Vasos.

80 Aférese de estuvo, var. de estivo.

81 Esta forma, utilizada varias veces nas narracións, tamén figura no texto mecanografado por Fidalgo.

82 Var. de rizón, áncora.

83 Var. de caer, tamén usada polo autor. 
— ¡Ai, Ricardín, bótame por Dios ${ }^{84}$ úa mao! ¡Axúdame, que me afogo!

Ricardo, posto en cucliyas ${ }^{85}$ nel borde del muelle, nun fía más que rirse, fendo que ya daba, a mao.

—Teis ${ }^{86}$ que cantarme el «nun me mates con tomates...».

Leonardo, entre sollozos ${ }^{87}$ i lágrimas, púxose a cantar mientras ${ }^{88}$ as olas moyábanye as pernas i el cul:

— «Nun... nun... me... mates, con... con... con... to... mates...». ¡Axúdame, que nun podo más!

As carcajadas ${ }^{89}$ dos mariñeiros del muelle oíanse en San Román. Por fin, Ricardo, coyéndoye os brazos, axudoiye ${ }^{90}$ a subir a terra i tomaron os chanqueiros de vino ${ }^{91}$ que nunca meyor ye souperon ${ }^{92}$.

Pero a festa i as bromas de este día trouxo cola. Dous meses de esto, foi Ricardo a Tapia i oío ${ }^{93}$ que lo chamaban. Era Dn. Sabino, el cura.

—Tía ${ }^{94}$ ganas de verte. Xa sei que andas dicindo ${ }^{95}$ por aí que eres ${ }^{96}$ fiyo meu. Pois mira..., nin ye fais ningún favor a túa madre nin tampouco a min. ¿Entendiche ${ }^{97}$ ?

\subsection{Pequeñas historias del $\mathrm{Eo}^{98}$}

Xa dixen el ano pasado que Ricardo taba dedicado al barcaxe i como nacera pra actor cómico, unde ${ }^{99}$ puido ser úa gran figura, i delo deu buenas pruebas ${ }^{100}$ nos

84 Cast., por Deus.

85 Cast., por crequenas.

$86 \mathrm{O}$ autor utiliza (en lugar de tes, fas, fan, teñen...) as formas temáticas orientais teis, fais, fain, tein..., variantes que teñen sido utilizadas cun rendemento esteticoliterario particular polo courelao Uxío Novoneyra (1981: 32, 67, 82...).

87 Cast., por saloucos, salaios, choros...

88 Cast., por mentres.

89 Cast., por gargalladas, risas...

90 A forma axudoi figura tamén na versión mecanografada.

91 Cast., por viño.

92 Var. de souberon. De igual xeito, soupo por soubo.

93 As formas en -ío (oío, vío, murío, abrío...), que nos poden lembrar a autores do occidente coruñés como Pondal ou López Abente, predominan sobre as en -iu (oíu, viu), utilizadas no galego común.

94 Na copia a máquina, Xa tía.

95 Repárese que o autor utiliza as raíces $d i c-$ e $d e c-$. A coincidente co castelán é a maioritaria.

96 Forma potenciada polo castelán. O autor utiliza es no sainete (¿Quen es tu pra insultarme?).

97 Var. que convive en todo o territorio galego coa máis utilizada hoxe na escrita, entendiches (Fernández Rei 1990: 88).

98 Utilizamos a edición das Figueiras de 1988, con algunhas correccións da man do autor, e a de 1997 da Caridá. O título, en castelán, contrasta coa «pequena historia» do ano anterior.

99 Var. de onde. Na edición de 1988, undo.

100 Cast., por boas probas. 
teatros de aficionados. El caso é que si se levantaba de buen ${ }^{101}$ humor a frase taba sempre a flor de labio i el chiste andaba con el como a sombra al corpo; pos nun había día que Ricardo nun inventase algúa toleiría ${ }^{102}$ que terminaban en risas i en comentarios: «este home é el mismo demonio ${ }^{103}$ », «lo que el inventa nun lo inventa naide ${ }^{104} \gg, \mathrm{i}$ as carcajadas estallaban ${ }^{105}$ entre os oyentes ${ }^{106}$.

Un día iba nel bote camín de Ribadeo levando a xente; había calma i os remos, sin prisa ningúa, entraban i salían nel agua pausadamente como fatigados de tanto eslapuzar ${ }^{107}$ día tras día. Ricardo iba calado con cara de circunstancias sin falar nada, cousa rara nel. Lola da Esquina, que iba nel bote, deuse cuenta i reparou que $\operatorname{algo}^{108}$ ye pasaba:

— ¿Pois que che pasa, Ricardín? Porque a ti algo che pasa; vas mui calado i nun dices ${ }^{109}$ nada.

Ricardo, con cara larga, voz baxa, mirou pra Lola i díxoye:

—Cale, muyer, cale; vou disgustado... ¿Nun sabe quen murío ${ }^{110}$ ?

—Ai, Ricardín del alma, nun me asustes; ¿pos quen murío?

- Ahora ${ }^{111}$ cuando $^{112}$ baxaba pral muelle dixéronme que morira ${ }^{113}$ de repente Don Víctor.

— ¡Ave María Purísima! Déixasme pasmada. Nin oín nada i einda ${ }^{114}$ ayer $^{115}$ lo vin en San Feliz falando con Manolo de Isidro.

-Nun somos nada, Lola, nun somos nada. Xa ves..., ayer tan campante i hoi ${ }^{116}$ xa morto.

101 Cast., por bo ou bon.

$102 \mathrm{Na} 1 .^{\mathrm{a}}$ edición, toleira. Nas falas galegoasturianas encontramos o sufixo -eiría como variante de -ería ou -aría.

103 Cast., por mesmo demo.

104 Forma coloquial moi utilizada en toda Galicia en lugar de ninguén.

105 Cast. (ou dialectalismo), por estalaban.

106 Cast., por oíntes (ou a comarcal ouguintes).

107 Batuxar.

108 Corrección manuscrita sobre al lago, incorporada na edición da Caridá.

109 As formas dices, dice e dicen, en lugar de dis, di e din, son características das falas do bloque oriental.

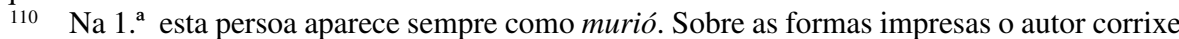
manualmente, cambios que xa incorpora a edición de 1997.

111 Cast., por agora.

112 Aínda que nas falas de Asturias se rexistre tamén esta forma, coidamos que o uso, por parte de Fidalgo, débese ao castelán.

113 Cast., por morrera. Como ocorre tantas veces na linguas subalternas, moitos falantes utilizan a forma castelá, morir, para as persoas e a galega, morrer, para os animais. No sainete, Fidalgo emprega tamén correctamente a tradicional.

114 Var. de aínda.

115 Cast., por onte (ou a comarcal anoite).

116 Var. de Asturias e parte de Lugo, en lugar da máis espallada hoxe, que podemos encontrar documentada noutros autores actuais (Rivas 2010: 98). 
Al chegar a Ribadeo embarcaba camín de Castropol Ramón Soto, juez ${ }^{117}$ comarcal da villa ${ }^{118}$, i nada más verlo ${ }^{119}$, Lola soltouye a noticia:

—Don Ramón, ¿nun sabe que murío Don Víctor das Figueiras?

_ ;Vaya por Dios! ¡Me deja Vd. asombrado! No sabía que estuviera enfermo.

—Éye que murío de repente fai mui pouco -aclarou Lola.

-No sé nada, porque al Juzgado no comunicaron nada. Ahora cuando llegue a Castropol me enteraré de lo ocurrido ${ }^{120}$.

A noticia correu como regueiro de pólvora entre a xente das Figueiras i as de Ribadeo que conocían a Don Víctor. Al subir a calle ${ }^{121}$ de Porcillán, Lola encontrouse con Don Alejo, cura de Piñera ${ }^{122}$, i deuye a noticia.

—Don Alejo, acabo de enterarme ${ }^{123}$ que murío Don Víctor de repente.

- Caramba, me deja Vd. frío; vaya desgracia tan inesperada.

Nun pasara media hora cuando atracou Candado con a súa lancha en Ribadeo traendo varios viaxeiros i entre elos ${ }^{124}$ a Don Víctor, que vía oficiar a un funeral en Ribadeo. Lola, que lo vío, botou as maus á cabeza i, santiguándose toda asustada, gritou:

— ¡Ai, Don Víctor del alma! ¿Vd. tá vivo ou é úa alma en pena? Acábanme de decir que morira $\mathrm{Vd}$. de repente.

Don Víctor, con $\mathrm{su}^{125}$ voz campanuda, lenta i doctoral, mirou pra Lola i espetouye molesto i displicente ${ }^{126}$ :

-Oiga, Lola, es de mal gusto bromear con la muerte, y yo no estoy muerto ni deseo estarlo, gracias a Dios. El que inventó ese meirolo ${ }^{127}$ más le valiera ir a los aguiyolos al Tesón para refrescar la cabeza.

Lola caieu entonces na cuenta de que todo fora úa falcatrúa ${ }^{128}$ de Ricardo.

-Déixaye que veña, que me ${ }^{129}$ vai oír... Foiye Ricardo, que me contou $l^{130} \mathrm{de}$ a súa morte -aclarou Lola-. Xa lo conoce como é; pero vaime oír, porque eso

17 Cast., por xuíz.

118 Cast., por vila (ou influencia do sistema familiar do autor).

119 O mantemento do $-r$ en verlo, encontrarlo, sacudirlos, etc. débese ao castelán. Contrasta esta formación coa máis enxebre utilizada no sainete: buscallo, allindallo, contallo...

120 A cursiva é nosa.

121 Cast., por rúa ou equivalentes.

122 Castelanización de Piñeira.

123 Cast., por saber ou similares.

$124 \mathrm{Na}$ área dialectal asturnegueiresa mantéñense os plurais etimolóxicos nas formas elos, estos, esos e aquelos, fronte ás formas galegas maioritarias, en -es.

125 Cast., por a súa.

126 Na 1. ${ }^{\mathrm{a}}$ desplicente.

127 Aldrumeirada, andrómena, argallada.

128 Trasnada, broma.

129 Falta na $1 .^{\mathrm{a}}$

130 O autor para o neutro utiliza lo e $o$ (cantaban o que yes daba a gana). 
nun se fai con úa persona maior. Perdóneme, Don Víctor, i alégrome que té vivo i Dios ye dé ${ }^{131}$ muitos anos de vida.

A cousa quedou así, pero, pasadas úas dúas horas, Ricardo volveu das Figueiras a recoyer a xente, i xa taba nel muelle Lola esperándolo ${ }^{132}$...

- Ah, condenado meiroleiro ${ }^{133}$, decícheme ${ }^{134}$ que morira Don Víctor i acabo de encontrarlo sano i vivo. Eso nun se fai, Ricardín; contácheme úa ${ }^{135}$ mentira i eu creínla ${ }^{136}$. I hasta ${ }^{137}$ yo dixen a Don Ramón Soto i a muitas máis personas que encontrei.

Ricardo, víndose ${ }^{138}$ descuberto, fíxose de novas i, medio enfadado, replicou:

-Déixeme en paz i nun me veña reñindo, que tou mui disgustado i nun tou pra nada. Acaba de caer del muro del muelle abaxo Rapela ${ }^{139}$ i abrío ${ }^{140}$ a cabeza. Leváronlo ${ }^{141}$ medio $^{142}$ morto sangrando como un cocho. Penso que a estas horas xa debeo ${ }^{143}$ morir.

— ¡Virgen ${ }^{144}$ Santísima! Nun gana un pra sustos -dixo Lola-. Hai días que más vale nun salir da casa. ¡Probe ${ }^{145}$ Rapela! Nun sabe un unde la ten. Mira tu que caer del muelle abaxo... Tamén é mala suerte ${ }^{146}$. $\mathrm{Si}^{147}$ abrío a cabeza, nun ten remedio.

-Pois non ${ }^{148}$ sei si tará morto -dixo Ricardo-; pois por a sangre ${ }^{149}$ que botaba i a cara que levaba, nun era pra esperar outra cousa. Parecía más morto que vivo.

Desembarcou Lola nas Figueiras i a pobre iba cavilando na desgracia de Rapela mentras subía por el muelle i, al pasar por delante del Bar de Rapela,

131 As formas té e dé debemos tomalas como castelanismos, en lugar de estea e dea (ou as comarcais (es)teña e día).

$132 \mathrm{Na} 1 .^{\mathrm{a}}$ esperándole.

133 Argalleiro, enredante.

134 Uso do tema de presente, $d e c-$, polo de perfecto, dix-, fenómeno moi frecuente na fala comarcal.

$135 \mathrm{Na} 1 .^{\mathrm{a}}$ una, que pode deberse a castelanismo ou a un intento de rexistrar a nasal de unha.

136 Cast., por crina (ou a local crinla).

137 Cast. popular en lugar da forma galega ata.

138 Var. comarcal por vendo.

139 Na 1. ${ }^{\text {a }}$ Rapiela.

$140 \mathrm{Na} 1 .^{\mathrm{a}}$ abrió.

141 Var., por levárono, tamén utilizada na área galegoasturiana.

$142 \mathrm{Na} 1 .^{\mathrm{a}}$ medo.

143 Fronte ao que ocorría cos verbos da terceira conxugación, nos en -er, a pesar deste caso, o autor inclínase máis polas formas en -eu (volveu, coyeu, atreveu...).

144 Cast., por Virxe.

145 Forma coloquial de pobre, empregada esta máis abaixo.

146 Cast., por sorte.

$147 \mathrm{Na} \mathrm{1.}{ }^{\mathrm{a}}$ Sio. Con esta solución, cabería pensar que a intención do autor puider ser ¡Si, ho! Si abrío...

148 Uso esporádico de non en posición átona, nas dúas edicións.

149 Cast., por o sangue. 
ábrese a porta i aparece Rapela ${ }^{150}$ con un pañuelo ${ }^{151}$ na cara estornudando a grito pelado. Lola sentío que ye daba mal i quedou parada mirando pra el fantasma que tía delante.

- ¡Ai, meu nenín, era meyor que Dios se acordara de Vd.! Sabe Dios como quedará del golpe; igual atolece ${ }^{152}$ pra sempre.

El aludido, sin quitar el pañuelo da cara, pos tía un catarro que nun gaznea$\mathrm{ba}^{153}$, mirou pra Lola i, dando media volta, meteuse dentro roñando pra si:

-Esta xa vai con el ala de a rastro ${ }^{154}$. Tuturruntaina ${ }^{155}$, tolete sin manga ${ }^{156}$. Al carajo $^{157}$, abanico. Vou tomar fervido na cama i aí me las ${ }^{158}$ den todas.

Ricardo nel bote aguantaba a risa que ye estallaba nas tripas.

Son pequenas historias dos marineiros ${ }^{159}$ del Eo que quedan na memoria da xente.

\section{4 [Chamábanye Antonón]}

Chamábanye Antonón i sempre taba armando das súas; por cualquer ${ }^{160} \operatorname{cosa}^{161}$ zorregaba sopapos; aunque ${ }^{162}$ tamén el cobraba algúas. Tía mui mala fama. Tocouye ir á guerra contra os franceses i alí encheuse de sacudirlos i tamén lo coseron a baionetazos; pero tía a pel de un sapo i curaba aos poucos días. Tía más cicatrices que pelos na cabeza. El caso é que, como ser humano, chegouye a hora de morir i, como fora mui devoto de S. Bartolo i sempre el día da festa iba á misa i rezábaye, al morir, chamoulo $\mathrm{pa}^{163}$ que lo recomendase a $\mathrm{S}$. Pedro. Este recibíolo ben i pa contentarlo meteulo nel Cielo ${ }^{164}$. Pasados úos días foi verlo S. Bartolo pa saber de el...

— ¿Tás a gusto aquí?

$150 \quad \mathrm{Na} 1 .^{\mathrm{a}}$ Rapíela.

151 Cast., por pano.

152 Entolece, louquea.

153 Garneaba, respiraba. A edición da Caridá incorpora unha corrección do autor sobre gozneaba, que figuraba na $1 .^{\mathrm{a}}$

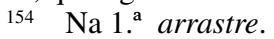

155 Paiola. Quizais formación popular sobre as castelás tontorrón e tontaina.

156 Sen goberno, sen solución (en sentido figurado).

157 Cast., por carallo.

158 Cast., por mas. As contraccións mo, ma, cho, cha... están presentes en todas as falas galegoasturianas, salvo nas dúas parroquias tixileiras, CI2 (véxase mapa).

159 Contrasta esta forma híbrida coa utilizada no título da narración anterior.

160 Cast., por calquera.

161 Cast., por cousa.

162 Cast., por aínda que.

163 Forma coloquial en lugar de $p(a) r a$.

164 Cast., por Ceo (ou a comarcal Celo). 
- ¡Vaia amigo que teño! -dixo Antonón-. Aquí, todos me abrazan i me chuchan ${ }^{165}$, hai muito silencio, muita paz i música dulce i, claro, nun podo dar úa trompada a naide. Esto nun foi feito pa min; eu quero barullo.

- Bueno, home, bueno... Vou levarte a outro sitio a ver si te encontras meyor -i meteulo nel Purgatorio.

Al cabo de úos días volveu verlo el Santo i Antonón, al verlo, acercóuseye i díxoye ${ }^{166}$ :

— ¡Vaia sitio que me trouxiche ${ }^{167}$ ! Aquí nun fain más que chorar i rezar i solo tein ganas de que los saquen. Si tán chorando e ${ }^{168}$ poinse de rodillas ${ }^{169}$ i estiran os brazos pedindo perdón, ¿a quen ye zorrego eu unha lafazada ${ }^{170}$ que me tán pedindo as maus? Xa che dixen que eu quero un sitio unde haia ${ }^{171}$ juerga $^{172} \mathrm{i}$ os sopapos anden por el aire. Nun podo tar parado más tempo.

-Bueno..., ven conmigo, que te vou levar a un sito ${ }^{173}$ de muito ${ }^{174}$ calor, i me parece $^{175}$ que lo vas pasar mui mal. Xa verás como te arreglas ${ }^{176}$; nun me veñas pedindo más cambies ${ }^{177}-\mathrm{i}$ meteulo nel Infierno ${ }^{178}$.

Pasados ocho ${ }^{179}$ días, foi S. Bartolo visitarlo i, nada más abrir a porta del Infierno, oíu a voz de este dando gritos $-\ll$ ¿Cerrar a porta que fai corriente ${ }^{180}$ !»- i seguidamente us golpes i un estarabouzar ${ }^{181}$, que mismo parecía que as paredes del Infierno caían a pedazos. Pasou pa dentro el Santo i viu a Antonón que tía agarrado por os cornos a un demo maior i dándoye ${ }^{182}$ con a cabeza contra un pote de ferro que taba nel lume colgado da gamayeira ${ }^{183}$, decíalle ${ }^{184}$ :

165 Bican, beixan.

166 No orix., dísoye.

167 Var. comarcal equivalente a trouxeches. Algunhas falas do galegoasturiano manteñen a vogal temática etimolóxica na segunda persoa dos perfectos fortes. $\mathrm{O}$ autor utiliza tamén tuviche por estiveches.

168 Fronte á forma maioritaria $y$.

169 Cast., por xeonllos.

170 Var. de labazada.

171 Cast., por haxa.

172 Cast., por pándega, xolda, polavila...

173 Véxase que, ademais de sitio, emprega a forma tradicional sito.

174 Cast., por muita.

175 Cast., por paréceme.

176 Cast., por amañas ou equivalentes.

177 Quizais un erro, por cambios. Pero tamén podemos pensar nunha substantivación partindo da forma de cortesía do imperativo.

178 Cast., por Inferno.

179 Cast., por oito.

180 Cast., por corrente.

181 Rebumbio, barafunda, balbordo..

182 No orix., deandolye. A grafía «ly» é produto da vacilación ante os grafemas «ll» e «y».

183 No orix., gamalyeira. Gramalleira, cadea de ferro para colgar na lareira os recipientes.

184 Lle fronte ao ye maioritario. 
— ¡Tate quieto, coño ${ }^{185}$ ! ¡Tate quieto, que te vou arreglar eu! Queimácheme nel cul i einda mandabas aos demos pequenos que me arrimasen un tizón aos $\operatorname{oyos}^{186} \ldots$ Ahora vas saber que[n] é Antonón i que conmigo ${ }^{187}$ nun valen demos, nin grandes nin pequenos... ¡Toma!

I soltouye úa patada na barriga, que largou al demo nel medio del lume. I, volvéndose pa detrás, coyeu a tres demos pequenos que taban queimándoye as cachas ${ }^{188}$ con us ferros calentes i, agarrándolos por el rabo, deuyes tres voltas por el aire i chimpoulos núa caldeira de agua ${ }^{189}$ fervendo.

-Aquí nun hai más demo que eu, Antonón. I el que nun teña ${ }^{190}$ contento, que se vaia prá terra.

En esto, viu a S. Bartolo i, soltando grandes carcajadas, dixo:

— ¡Esto xa é outra cousa! Aquí é verdá ${ }^{191}$ que lle zorregan a un; pero tamén las levan. En todo el día nun paro de sacudir aos demos. Queimar si que me queiman; pero douyes cada centellazo..., que los volvo tolos. Pásolo mui ben i mui entretenido $^{192}$. Nun me saques de aquí... I xa podes volver pá iglesia ${ }^{193}$ de Piñeira, que é o ${ }^{194}$ tou sitio. I mira por os vicíos...; alíndalos ${ }^{195}$.

Deu media volta i marchou ${ }^{196}$ correndo detrás del demo maior, que acababa de salir del lume.

Hasta aquí la leyenda de Antonón tal como está escrita en un viejo pergamino del archivo parroquial.

\subsection{El juego de brisca original de Antonón i outras cousas ${ }^{197}$}

Xa contei el ano pasado a afición que tía aos amarramentos Antonón i tamén lo que ye pasou al morir axudado por San Pedro. Pero nun yes contei as diversiois ${ }^{198}$ cuando era mozo i einda nun fora pra a guerra. Antonón nacera en

185 Cast., por cona, cunhas connotacións expresivas equivalentes a caraina, carafio e similares.

186 No orix., oyes.

187 Cast., por comigo.

188 Nádegas.

189 Var. que moitos falantes, por influencia castelá, priorizan ante auga e augua, usadas por Rosalía en Cantares gallegos.

190 Aférese de (es)teña.

191 Var. coloquial de verdade.

192 Cast., por entretido.

193 Cast., por igrexa.

194 No orix., eo. Obsérvese que resulta esporádico o uso do artigo $o$ (fronte ao maioritario el).

195 Cóidaos, gárdaos.

196 No orix., marchoy.

197 Utilizamos a primeira versión impresa con pequenas correccións manuscritas feitas polo autor. Chama a atención o título híbrido de castelán e galego.

198 Plural propio das falas do bloque oriental, por diversións; igual que mirois, que aparece máis abaixo. Na literatura, os plurais en -ois están amplamente documentados, desde os inicios do Rexurdimento, na obra de Fernández y Morales (2003: 279-297). 
Castiñeirúa ${ }^{199}$ i alí vivío hasta que lo chamaron pra coyer el fusil, que era lo que el quería. Menudas ${ }^{200}$ animaladas armou...; porque, a bruto, nun ye ganaba naide. Xa sendo novo, aló por os diecisiete ${ }^{201}$ anos, era el más tolo del lugar i todos ye tían medo. Amarrábase por calquer ${ }^{202}$ cousa i tanto ye daba que foran grandes ou pequenos, gordos ou flacos ${ }^{203}$, veyos ou novos. Todo ye valía pra sacudir centellazos. Claro que algú[a] vez tamén salía con un oyo a la funerala; pero eso eran cousas del oficio, decía el. Na súa casa eran labradores probes i tía que trabayar, pero pasábaye como a Fernandín de Serantes, que decía que tía mui bon corpo; pero, si traballaba, dolíanye os cadriles. A Antonón tamén ye dolían os cadriles i sempre taba esperando a noitía ${ }^{204}$ pra ir a úa taberna que había en Valín pra botar a partida de brisca con sou vecín Pepe del Molín. Levaban jugando ${ }^{205}$ todos os días xa fía la $^{206}$ mar de tempo i conocían$\mathrm{se}^{207}$ más que si foran ermaos ${ }^{208}$. A este nun ye pegaba porque ye aguantaba todo i, además, Pepe era froxo i pequeno i, si Antonón ye daba un soplamo$\cos ^{209}$ un pouco terciado, el probe de Pepe salía por os aires ou quedaba descuajaringado ${ }^{210}$ pra sempre.

Xugaban á brisca, que ten pouco que pensar. Miraba a la carta que acababa de coyer i era sabido que, si ye gustaba, cantaba entre dentes:

-Ai, Tomasa, que me abrasas.

Si a que coyía nun era buena rezaba por lo baxo:

-Tate por eî ${ }^{211}$, que xa me rascarás.

Tanto si perdía como si ganaba, tomaba un vaso de vino.

Falaba con as cartas i guiñábayes ${ }^{212}$ os oyos como si foran mozas solteiras. $\mathrm{Si}$ la carta era mui mala decía:

—É boa cría, si dera leite.

199 No orix., Castiñeurúa.

200 Cast., por miúdas.

201 Cast., por dezasete.

202 Cast., por calquera.

203 Cast., por fracos.

204 Var. asturnegueiresa equivalente a noitiña. O sufixo -ía, o mesmo que -iña, resulta de moito rendemento literario (Conde 2000).

205 Cast., por xogando.

206 Cast., por $a$, xa usado na mesma expresión por Rosalía de Castro (1880: 170). Nesta narración encontramos outros casos en la funerala, la carta...

207 Cast., por coñecíanse.

208 Var. de irmaos, forma galega centrooriental en lugar de irmáns.

209 Cast., por sopramocos.

210 Cast., por descomposto, escacharrado, estragado e similares.

211 Var. de aí.

212 Cast., por chiscáballes. 
Si era mui buena ${ }^{213}$, comentaba soltando un guiño ${ }^{214}$ picaresco:

-Chúchame nel cul que vou pra Brul -i arrastraba de triunfo.

Úa noite que taba xugando a partida cantou ${ }^{215}$ as cuarenta $^{216}$. Pepe del Molín mirou pra Antonón i espetouye:

-Eso si que é raro.

—Que é lo que é raro -preguntou Antonón.

- Coño, eu sempre pensei que pra cantar as cuarenta hai que tener ${ }^{217}$ el rei i el cabalo.

-Pois claro que hai que terlos, pero nun fai falta que señan ${ }^{218}$ del mismo palo; basta que teñas un cabalo i un rei do ${ }^{219}$ que sea.

Pepe mirou estrañado i calou.

-Entonces vouche cantar eu outras cuarenta; porque teño el rei de espadas i el cabalo de bastos -dixo Pepe.

Antonón nun dixo nada i desde entonces cantaban en falso i cantaban o que yes daba a gana. Ganaba el que más veces cantaba i así foron jugando desde aquel día. A brisca xa nun era brisca, era úa toleiría. Cada un cantaba cuando ye daba a gana i todo valía. Os mirois que se deron cuenta del xuego ${ }^{220}$ novo inventado por Antonón, primeiro taban calados, despois botaban a rirse i como a risa nun ye gustaba a Antonón porque lo tomaba a burla, úa noite pegou un brinco del tayolo ${ }^{221}$ en que taba sentado i, soltando as cartas, berrou:

—De min nun se ri naide i delante de min tampouco...

I a dous mirois que taban más cerca soltouyes con dúas maus úas narniadas ${ }^{222}$ que yes ${ }^{223}$ fexo $^{224}$ caier de focicos ${ }^{225} \mathrm{i}$ botar a correr antes de que caiese outra lafazada.

Desde aquel día naide se acercaba a mirar i Antonón i Pepe del Molín xugaban á súa manera ${ }^{226}$ cantando o que yes daba a gana, i el que máis cantaba ganaba a partida bebendo el vaso de vino sin costarye nada. El taberneiro, que

\footnotetext{
213 Contrástese este cast. coa forma galega boa, utilizada anteriormente.

214 Cast., por chisca, chiscadela...

215 O autor introduce ou manuscrito sobre unha forma impresa.

216 Var. de corenta.

217 Cast., por ter.

218 Var. de sexan. Véxase tamén a continuación a forma sea.

219 Corrección manuscrita sobre $d e$.

220 Cast., por xogo.

221 Tallo, banqueta.

222 Labazadas, lapadas.

223 No orix., xes.

224 Var. de fixo.

225 Var. de fociños.

226 Cast., por maneira, xeito...
} 
era un caguitas ${ }^{227}$ i tíaye más medo a Antón que a un lobo núa noite de inverno, nunca se atreveu a cobrar os vasos de vino que servía i, dous anos despois, os franceses que pasaron por Piñeira bebéronye todo el vino i fusiláronlo por esconderlo nel desván envolto en herba seca. Antonón andaba por Castilla ${ }^{228}$ fendo das súas, que era matar franceses.

Había un suceso que Antonón calaba i que solo lo sabían us poucos. Fora antes de chamar a súa quinta. Aló por el ano 1802, sendo rapaz, mandouye sou padre buscar leña pra a cocía ${ }^{229}$. Era nel inverno, caiera úa nevada que cubrira casas, prados i montes; porque naquelos tempos nevaba más que ahora i fía muito más frío. Os lobos nun andaban mui lonxe porque de noite oíanse ${ }^{230}$ os aulli$\operatorname{dos}^{231}$. Salío Antón con a burra, pero cuidou ben de levar debaxo da zamarra un cuchillo $^{232}$ da matanza, por si acaso. Chegou al monte i amarrou a corda del cabeceiro nun pino $^{233}$, deixando que a burra pacese mentras buscaba a leña.

Cuando más enfaenado taba nel sou trabayo, ouío que el animal berraba con úa voz rara como si se afogase. Nun fixo caso, pero lougo ${ }^{234}$ úa idea pasou por a súa cabeza i salío correndo pra unde deixara a burra. Cando ${ }^{235}$ entre os pinos puido ver, a sangre xelóuseye nas venas ${ }^{236}$. Dous lobos taban devorando a burra. A presencia ${ }^{237}$ da burra morta i ensangrentada encendeuye a sangre $i$ Antonón, como un tolo, clavou ${ }^{238}$ el cuchillo na barriga de un lobo i, sin esperar sacarlo, atortorou ${ }^{239}$ con as maos el pescozo del outro lobo i, despois de muito trabayo i escrocarye ${ }^{240}$ el focico afogándolo contra os brazos, fíxoye tumbarse i quedou med[i]o morto. Como Antonón queríalo vivo, púxoye de freno $^{241}$ na boca un lazo corredizo con a corda da burra morta, amarrouye ben el pescozo, apareyouye a albarda apretando ben a cincha ${ }^{242}$ i cargouye a leña que iba levar a burra. El lobo, al volver en si, reculaba, bufaba, negábase [a] andar i nun podía con el sin fer caso dos mandatos de Antonón.

- ¡Conque matácheme a burra i ahora nun ques levar a carga da leña...! ¡Xúrote ${ }^{243}$ por Dios que vas a obedecer si nun é por as buenas vai ser por as malas...!

Cast., por cagado, cagainas, caguelo...

Cast., por Castela.

Var. de cociña.

Corrixido sobre outra forma impresa.

Cast., por oulidos, ouleos, ouveos.

Cast., por coitelo.

Var. de piñeiro.

Var. asturnegueiresa por logo. De igual xeito, llougo.

Repárese na alternancia de cuando e cando.

Cast., por veas.

Forma popular en lugar de presenza.

Cast., por cravou.

Comprimiu, apertou con forza.

Desnarigarlle, esmagarlle.

Cast., por freo.

Correa, corda ou faixa estreita que abrangue a barriga do animal para asegurar o aparello.

Por xúroche. Uso incorrecto de te, teísmo. 
Coyeu úa estaca i a cada paso que el lobo daba pra tras, estacazo que ye caía. Tiraba del cordel como un condenado, pero a estaca ablandouye os ánimos i por fin amansou i os golpes fixéronlo cuerdo ${ }^{244}$. Muitos levou, pero tamén tein muito aguante. Xa un tanto calmado, levoulo por el ronzal i así entraron nel pueblo $^{245}$ i chegaron á casa, asustados os vecíos de ver o que veían ${ }^{246}$. Os cais $^{247}$, que lo oliron ${ }^{248}$, saliron todos detrás i armouse úa festa de ladridos, que alí nin se podía falar ni oír nada. Descargoulo da leña i, como os cais nun calaban, os vecíos tampouco querían aquel vecín, Antonón chamoulos i, dándoyes el lobo, díxoyes:

-Ese é pra vosoutros, el outro xa quedou morto nel monte. Fede ${ }^{249}$ de el un pandeiro.

Un vecín que era cazador tirouye dous balazos i aquelos lobos nun mataron más burras na súa vida. De esto Antonón nun quería falar, aunque todos lo sabían, pero era recordado como úa hazaña ${ }^{250}$ que solo Antonón era capaz de fer.

\subsection{A noite da garfella ${ }^{251}$}

A Octavio, el gaitero de «Los Penácaros» ${ }^{252}$, al que leí este suceso hace veinticinco años y hasta hoy no ve la luz pública».

En las proximidades de Boal tuve amores. Era la moza garrida y galana, guapa como la primera y bien plantada. Llamaba la atención. La conocí en la feria de Boal, en el paseo final que en tal día se organizaba. Su padre anduviera por las Américas y al regreso casó con moza rica en tierras, de donde se vino a juntar los pesos de él y la casería de ella.

La casa, palacio de los Trastamaras, era maciza y señorial, con su torre y escudo, jardín fronterizo y, más allá, huertas, prados y montes. Estaba en el camino real, a un tiro de piedra de la principal. De este matrimonio nació Rosaura, sobre la que convergieron mimos, atenciones y regalos. Si bien en un principio la enviaron a la capital a educarse, pronto lloraron su falta y la trajeron a la casona para acompañar a los padres, que sin ella no vivían.

Los jueves y domingos iba a verla, recorriendo por cañadas y veredas la hora larga de camino que nos separaba. ¡Oh tiempos aquellos de mis veinte años, qué lejos quedáis!

Cast., por cordo.

Cast., por lugar.

Cast., por vían.

Forma propia das falas do bloque oriental, por cans.

Cast., por uliron.

Var. de facede.

Cast., por fazaña ou similar.

No orixinal figura o título en cursiva encerrado entre comiñas.

Para coñecer máis de Octavio e do seu labor musical, vid. Suárez 2006b: 154-156. 
¡Qué importaba para un mozo enamorado los fríos, las lluvias y el viento, el caminar a deshora!

No olvidaré jamás las horas pasadas en la cocina aquella, conventual y espaciosa como una plaza, de grandes armarios y vasares, de monumental campana, bajo la cual ardían viejos troncos de encina y a cuyo calor me acunaba oyendo afuera el rugir del viento y el batir de la lluvia.

María, la anciana sirvienta, contaba cuentos de trasnos y brujas con patetismo de sibila y el candil de acetileno, con su vacilante luz, ponía un fondo misterioso y fantasmal. La imaginación de Rosaura volaba ora por regiones de ensueño, ora por tinieblas de terror, suspirando dolorida por los males que pudieran acaecerme en la soledad de la noche.

Tres días hacía que llovía sin cesar. El vendaval convertía la lluvia en cortina cegadora y los árboles se encorvaban y gemían por la furia del huracán. Tierras y caminos eran un mar de agua y la naturaleza entera, gemibunda, oía su voz en la soledad de los campos y montes. Era un mundo muerto, sepultado por el agua y arrastrado por el ciclón.

Desoyendo consejos y apartando prevenciones, fui al lado de Rosaura. La voz de María suena aún en mis oídos.

— ¡Ay, probín! $!^{253}$ Salir en esta noche es tentar a Dios. Mira como viene, empapado de agua y barro. En noches así anda el diablo suelto. ¡Es tentar a Dios..., es tentar a Dios! $!^{254}$

Los ojos de Rosaura, turbios de emoción y lágrimas, me hablaban de amor y paz y su mirar compensaba mis quebrantos. Fue, sobre todas, una velada feliz. El viento aullaba en la chimenea, revolviendo humo y ceniza. María dormitaba en una banqueta al calor de los leños, teniendo a sus pies al mastín cancerbero del hogar. Los ramalazos de la lluvia se estrellaban en los cristales con monótono repiqueteo. Respaldado en el vasar y sobre el escaño viví horas felices contemplando las llamas y el crepitar de los troncos.

Rosaura sollozaba al verme partir. En verdad que la noche encogía el ánimo. La tempestad seguía en todo su furor. Enfundado en el impermeable me lancé a la boca de la noche. El fragor del temporal extremecía al más valiente. Los caminos eran ríos y los bosques gemían como alma en pena. La negrura de la noche era como pozo sin fondo. Al saltar un charco sentí un golpe en la espalda. Miré y no vi nada. Un escalofrío recorrió mi cuerpo. Las palabras de María martillaban mis oídos: «¡En noches así anda el diablo suelto! ¡Es tentar a Dios..., es tentar a Dios!».

253 As cursivas son nosas.

254 Sabemos que Fidalgo publicou dous textos que non citamos na relación, «Un ayer muy lejano del Franco» e «Es tentar a Dios», dos cales nos foi imposible acceder aos orixinais. Quizais couber a posibilidade de que o segundo tivera que ver con esta narración que ofrecemos. 
Mi caminar se convirtió en carrera y las llamadas en la espalda se sucedían a intervalos, unas veces más suaves y otras más fuertes, como si una mano invisible llamara mi atención. Si en los comienzos volví la vista atrás, después ya no pude y corría y corría alocado, chapoteando en el agua y calado hasta los huesos.

Sólo recuerdo que, aturdido y sin aliento, entré en mi casa y encendí la luz. Estaba solo. Miré atrás y no había nadie. Mi cerebro coordinó sus pensamientos y pensé que era un sueño. El miedo fue quien me hizo vivir la pesadilla, no podía ser otra cosa. «Fue el miedo, sí, fue el miedo», me decía. ¿Quién me iba a golpear en la espalda?

Convencido de ello, encendí un cigarrillo y, agotado, me dejé caer en una silla.

En este instante un golpe secó sonó en mis espaldas. Sin saber cómo, me encontré en el extremo opuesto de la estancia, empuñando la escopeta de caza y haciendo frente al enemigo misterioso. Crispado, apreté los gatillos.

En el suelo, y todavía valanceándose, pude contemplar una garfella -garfilla-, que indudablemente pertenecía a la cocina de Rosaura y que yo había traído colgada del cuello del impermeable, dándome los golpes en mi carrera desenfrenada.

Desde entonces, a las noches tempestuosas se les llama noites da garfella.

\section{7 [As dúas riquezas]}

\begin{tabular}{ll}
\multicolumn{2}{c}{ REPARTO } \\
Inés & La tía Pepa \\
Lorenza & Juanita \\
Pardo M. & Antón \\
Ónega Llanes & Bonifacio \\
Vázquez Paredes & Isidro
\end{tabular}

La acción, en una casa de labradores, en la cocina. Época actual.

Al levantarse el telón estarán en escena la TÍA PEPA, mujer aldeana, y JUANITA, hija suya, ya moza; las cuales vestirán al uso del pueblo: pañuelo a la cabeza, la primera amarrado sobre la misma y la segunda debajo de la barba; las dos con madreñas en los pies, con los llamados escarpíos ${ }^{255}$. En el pecho y sobre la falda, la toquilla, atravesada como se usa ordinariamente. Ambas llevarán mandil.

PEPA, sentada junto al fuego, le soplará de vez en cuando y revolverá en la olla y en los intervalos mondará patatas. JUANITA estará en un banco, no muy lejos, calcetando.

255 Calcetíns de la grosa, escarpiños, escarpíns. 
PEPA: $\quad$ Pois $\mathrm{o}^{256}$ que che digo i che repito... Éche que Bonifacio é un bocado ben bon; ¡ai é, ho! Pos mira tu que vir de América despós de tar alló diecioito ${ }^{257}$ anos... Éche que vén ben forrao ${ }^{258} ;$ ¿nun che parece?

JUANITA: Home, xaora. Eso penso eo ${ }^{259}$, pois además os relojes de oro ${ }^{260} \mathrm{i}$ os ani$1 \operatorname{los}^{261}$ nun se compran con dous perrois ${ }^{262} \ldots$

PEPA: $\quad$ Pos mira, tu nun seas boba i xa que parece que nun ye disgustas i che fai festas..., aprovéchate ${ }^{263}$, porque este mundo éche pra os vivos i pra os aprovechados.

JUANITA: Home, nun diga tolluras; ¿i el probe Antón?

PEPA: $\quad$ Pos mira tu que teis cousas... ¿I que tapa Antón al [llao] de Bonifacio? Ademais, cada un é mui amo de si mi[smo i] de fer lo que ye dé a gana.

JUANITA: Home; pois a min dáme pena del; ¡tan infelizón i [tan] enemorado ${ }^{264}$ !

PEPA: $\quad$ ¡Macanas, chica, macanas! Como dice Bonifacio -i [ten muita] razón-. Pos mira tu (levantándose y dándose una m[anotada] en sus robustas traseras) en que repara. Si tá en[emorado] i a ti che chega outro, que che conveña máis, xa s[ea por] esto ou por lo outro ou por lo de máis alló, eso a [el nun] ye importa, i que aguante, que pra eso nacemos. ¿Vasye cerrar a porta á fortuna? ¿Quen desperdicia un dulce, nía ${ }^{265}$ ¡Cua ${ }^{266}$ escasez que hai de us i doutros! Pos mira tu..., cúidame del llume, que vou mecer $^{267}$ as vacas, i nun che se esqueiza ${ }^{268}$ lo que che dixen. (Caminando hacia la puerta). Tein estos canallas de agora cada cousa...

ANTÓN: $\quad$ (Mozo del pueblo, fuerte y tosco, vestido pobremente y a la usanza; con madreñas en los pies. No quitará la gorra y estará siempre fumando). ¡Búas noites, Xuana!

JUANITA: ¡iMui buenas, Antón! ¿Que $\operatorname{cuntas}^{269}$ ? ¿Que hai de novo por el pueblo?

256 Corrección manuscrita sobre pos lo.

257 Forma híbrida, co primeiro elemento en castelán, por dezaoito.

258 Forma coloquial en lugar de forrado.

259 Var. de $e u$.

260 Cast., por reloxos de ouro.

261 Cast., por aneis ou sortellas.

262 Moedas de dez céntimos de peseta, patacóns, cans.

263 Cast., por aprovéitate.

264 Var. de namorado.

265 Aférese de nenía, var. asturnegueiresa de neniña.

266 Var. de coa.

267 Muxir, munguir, moncer. É, xunto con mocer, unha forma propia das falas galegoasturianas (Dubert + Sousa 2002: 195 e Fernández Vior 1998: 212).

268 Var. de esqueza.

269 Var. de contas. 
ANTÓN: $\quad$ Pos por el pueblo hai abondo i mal repartido i tamén abondo pra puer ${ }^{270}$ a un de mal coraxe ${ }^{271}$. (Sentándose y liando un cigarro).

JUANITA: Será verdá, home, que a xente é el mismo demonio. Pero, ¿que se dice? ¿De que marmuran ${ }^{272}$ ? (Suspendiendo la labor).

ANTÓN: Pos marmuran, ¡fíjate ${ }^{273}$ !, de ti misma, é decir, de min.

JUANITA: (Mirando extrañada). ¿De min? ¿I que poden decir de min, Antón ${ }^{274}$ ?

ANTÓN: Pos de ti poden decir lo que yes dé a gana. ¡Quen yes quita! Ademais, condo $^{275}$ el río suena ${ }^{276} \ldots$ Xa me entendes.

JUANITA: Dios me axude... ¡Tu, tamén! Tamén tu, en quen teño máis ${ }^{277}$ fe. (Tapando la cara con el mandil y lloriqueando).

ANTÓN: Calla, muyer, calla, i sigue tendo fe, que quen nun la vai tendo soi eo. A cousa nun é pra tanto, e, ademais, todo ten remedio.

JUANA: (Compungida). Dime que dicen ${ }^{278}$. ¿É muito pecado?

ANTÓN: Pos dicen lo que eo taba olendo ${ }^{279}$ xa hai tempo; que ye dás entrada a ese pamplinas de Bonifacio, que, porque tuvo na América muitos anos sirvindo $^{280}$ de jumento ${ }^{281}$, xa pensa que aquí nun hai más que chegar $\mathrm{i}$ encher. I eo penso que por túa madre nun virá.

JUANITA: Bueno... ¿I que?

ANTÓN: Xa hai tempo que lo veño observando, que che regaña muito os dentes de oro i che canta muitos tangos; ¿non? ¡I parece ${ }^{282}$ que esa arte dá resultado! ¡Pinta mentira!

JUANA: (Disgustada). ¿Hai algo máis?

270 Var. de poer, alternativa comarcal de poñer.

271 Cast., por mala coraxe.

272 Var. de murmuran.

273 Cast., por fixate.

274 Incorporamos a forma manuscrita á oración interrogativa que a precede.

275 Var. de cando, utilizada por escritores de Asturias e León (Poncelas 1995: 78).

276 Cast., por soa.

277 Respectamos a forma mecanografada, a pesar de que a riscada sobre o $i$ puider interpretarse como a eliminación desta letra.

278 Tendo en conta o signo de interrogación, cabería estoutra interpretación: Dime... ¿Que dicen?

Cast., por ulindo.

Var. coloquial de servindo.

Cast., por burro.

O borrón sobre o $e$ quizais nos deba facer pensar na forma parez. 
ANTÓN: (Largando un salivazo por un colmillo). Lo malo é que a min tame rabincando $^{283}$ el corpo tamén por cantar, i eo nun sei cantar sin acompañamiento ${ }^{284}$; ¿enténdesme? (Con ademán de pegar).

JUANITA: (Tirando la calceta sobre la mesa). Mira, tu... ¡xa bastou! Soi mui due$\tilde{n} a^{285}$ de fer lo que me dá a real gana. I si me gusta ou nun me gusta Bonifacio, lo mismo que si ye dou entrada, nun che importa, nin a ti nin a naide.

ANTÓN: $\quad$ (Poniéndose de pie y atusándose la barba). Pos... ¿sabes lo que che digo? Que así mismo contestaría úa grandísima y aventajadísima ${ }^{286}$ fiya da $[\ldots]^{287}$. Claro..., dime con quen andas... Sempre algo se pega. Pronto che fixeron efecto os tangos i as gringuadas 288 . Tía razón el que dixo: «si nun ques ${ }^{289}$ ver a paz nunca alterada, cree ${ }^{290}$ muito en Dios i nas muyeres nada». Bueno..., pra acabar, tás conforme con lo que a xente murmura; ¿nun é eso?

JUANITA: (De malas maneras). Tou conforme con lo [que] eo quero i me dá a gana. Tá dito.

ANTÓN: $\quad$ Bueno, pos ahora tócame decir lo que quero eo. Si ese marica (recalcando) sigue vindo aquí a decirche gringuadas, eo virei a decirche gallegadas, que se entenden ${ }^{291}$ meyor, i mira que, aunque a min me regañe os dentes de oro, nun che me asusta nin me dorme. Corre el peligro de que yos quite pra poñerchos ${ }^{292}$ a ti, xa que tanto che gustan. Ahora que..., si chos poño, ha de ser nel sitio das molas del xuício ${ }^{293}$, porque... paréceme que nun las teis.

JUANA: (Interrumpiendo y levantándose enfadada y gritando). Mira que nun te quero oír máis, que chamo a mía ${ }^{294}$ madre.

ANTÓN: (Cortando la conversación). Menos ruído, que é casa baxa. Ahora falo eo i einda nun acabei.

JUANA: (Gritando). Nun me dá a gana; tou na mía casa pra falar lo que quero. ¿Quen es tu pra insultarme? (Poniéndose en jarras y taconeando con mucho meneo del trasero). Pos pra que lo sepas, de aquí en adelante nun volvas a pisar esta casa i si Bonifacio me gusta é porque lo merece. ¿Tu que pensabas, probetón? (Riendo irónicamente). ¡Meu probe! Bonifacio

\footnotetext{
283 Var. de reb(r)incando, fervendo.

284 Cast., por acompañamento.

285 Cast., por dona.

286 Cast., por avantaxadísima.

287 Por mor do riscado, non podemos identificar os caracteres mecanografados.

288 Var. de gringoadas, gringadas.

289 Forma coloquial de queres.

290 Cast., por cre.

291 No orixinal, ententen.

292 No orixinal, ponerchos (véxanse tamén duena, castano, etc., por dueña, castaño etc.).

293 Var. coloquial de xuízo.

294 Var. asturnegueiresa de miña.
} 
sabe falar i sabe presentarse unde quera ${ }^{295}$, lo que tu nun sabes. Ademais, é un bon mozo i é rico. ¡Ala..., amolarse!

ANTÓN: $\quad$ (Muy meloso). Xa lo sei, muyer; xa lo sei. Pero, ¿pensas que eu nun sei decir esas cousas igual que el gringo? (Imitando al gringo). ¡Ay...! (Pasándole la mano por la mejilla). Vos sois mi bella prinsesa (queriendo besarla).

JUANA: $\quad$ ¿Quita de eí, agoirado 296 ! (Yendo a sentarse).

Se oyen las madreñas de la madre, que viene, y ellos vuelven a ocupar los mismos asientos, continuando Juanita la labor.

PEPA: ¿Que hai, Antón?

ANTÓN: Pouca cosa ${ }^{297}$, tía Pepa.

PEPA: ¿Fostes ${ }^{298}$ al monte?

ANTÓN: Si, fomos esta mañá299. (Cogiendo con mucha precaución una mano de Juanita y arrimándose a ella como para comerla). ¿El tío Isidro einda nun veo?

PEPA: $\quad$ Ese..., el que lo busque xa sabe unde tein ${ }^{300}$ que ir a buscallo ${ }^{301}$ : á maldita taberna.

ANTÓN: (Queriendo besarla ${ }^{302}$ la mano, y no pudiendo). Malo, malo, malo... Mala escola é esa pra aprender nella. É verdad ${ }^{303}$ que trabayador é muito; pero, bebedor i muyerego..., tamén ye tocou a súa tayada.

PEPA: $\quad$ (Soplando el llume después de guardar los dos canados de leche que trajo). É verdad, ho, é verdad; é mui bueno i mui cariñoso; pro, aos sous anos, xa nun debía fer eso. Que pase xa lo que bebe... ¡ Pro $^{304}$ mira tu que, aos sous anos, írseye os oyos detrás das mozas...! ¡Zúmbaye el perrengue $^{305 !} ¡ \mathrm{Ai}$, ho...! ¡I que ye fagan caso! ¡Ben condenadas tán as muyeres! ¡I como si eo nun vivira! El mamalón ${ }^{306}$ ten pra todas. Si me volvera moza..., outro gallo ye cantara; ¡dígocho eo! ¡Claro..., despós

295 Var. de onde queira.

296 Agoiro, molestador.

297 Cast., por cousa.

298 A pregunta, así como a resposta, alude á colectividade familiar.

299 Parece existir unha primeira forma, mañana, cunha sobreimpresión para borrar os últimos caracteres.

300 En lugar desta persoa de plural, cabería esperar, tendo en conta o suxeito, o singular ten.

301 Cast., por ir buscallo, forma propia da área de palatalización, por ir buscalo.

302 Sorprende este laísmo. Quizais habería que supoñer besarla [en] la mano.

303 Cast., por verdade. Do mesmo xeito, debilidad, barbaridad, sociedad... por debilidade, barbaridade, sociedade...

304 Var. de pero.

305 Manda truco!, ai que ver!, róncalle o pexegueiro! etc.

$306 \mathrm{O}$ riscado non permite ler as formas mecanografadas primeiras. 
vén prá casa i nun pensa más que en dormir! Pero... ¡ ¡hei de allindallo ${ }^{307}$ eo! Somos tan fatas i vosoutros tan meiroleiros ${ }^{308}$, que nos engañais ${ }^{309}$ como queredes.

ANTÓN: $\quad$ (Robándole un besito a Juanita y recibiendo un cachete. Mientras se palpa la cara). Non como queremos, ¡centeya! Si fora como queremos, ¡miau que te papo! (Haciendo como que come a Juanita).

Se oye dentro cantar en voz baja, lo bastante alta para que el expectador la oiga: Porque sé que estás triste y cantar ya no puedo ${ }^{310} \ldots$.

BONIFACIO: (Entrando). ¡Muy buenas noches, señores! (Vendrá vestido con traje blanco, el pantalón muy corto y estrecho, usará lacito negro con cuello almidonado muy alto, de los antiguos, puños un cuarto de lo mismo y colgará de su cuello unos impertinentes ${ }^{311}$, los cuales se enfundará cada vez que habla con alguien. Llevará de bolsillo a bolsillo del chaleco, y atravesada, una gruesa cadena, ya de oro ya de metal amarillo, y tendrá un bastoncito al cual le dará unas vueltas elegantes en el aire).

TODOS: ¡Muy buenas! (Juana lo mirará sonriente y provocativa).

BONIFACIO: ¡Pucha ${ }^{312}$, que frío hase...! (Frotándose las manos y soplando en ellas). Yo amo con delirio estos hogares apasibles, callados y novelescos, en los cuales siempre existe la bella prinsesa durmiente (mirando sonriente a Juanita. Todo lo dirá con marcado acento argentino y al mismo tiempo se quitará la gabardina).

ANTÓN: (Que lo estará mirando con burla y meneando la cabeza como compadeciéndose. Marcando en la sien con un dedo y cantando). Que tou pai nun lo ten, que túa mai nun cho dá... ${ }^{313}$.

BONIFACIO: (Poniéndose serio). ¡Ah! Pero tenemos gente extraña... ¡Pucha...! Y yo sin darme cuenta (calándose los impertinentes y mirando muy estirado). ¿El señor es amigo de la casa?

PEPA: $\quad$ Si (muy amable); é Antón, el fiyo del tío Blas; ¿nun te acordas? (Abriendo mucho la boca).

307 No orixinal, allindarllo.

308 Meiroeiros, afagadores, aduladores.

309 Cast., por enganades.

310 Fragmento do tango «Bandoneón arrabalero» de Bachicha e Contursi (1928)... Bandoneón, / porque ves que estoy triste y cantar ya no puedo, / vos sabés / que yo llevo en el alma marcado un dolor.

311 Tipo de anteollos que, en lugar de patillas, contan cunha variña vertical para sostelos.

312 Interxección de sorpresa.

313 Variante dunha cántiga popular moi coñecida... Túa nai non o ten / e teu pai non cho dá / e ... ¿ ¿de onde che sae? / Do teu trailalalá. / Do teu trailalalá, / do teu trailalalá... / Túa nai non o ten / e teu pai non cho dá. Outra variante do mesmo tema é tamén utilizada por Cotarelo Valledor ao comezo de Beiramar. 
BONIFACIO: (Muy ceremonioso, inclinando medio cuerpo y estirando su mano enguantada). El señor perdone. Tanto gusto. ¿Vos sigués ${ }^{314}$ bien y la familia?

ANTÓN: (Levantándose pausadamente y rascándose el trasero y haciéndole esperar al otro en la postura estirada e incómoda que adoptó al saludar). Déixate de pamplinas, Bonifacio, que ben nos conocemos (le coge la mano y se la aprieta duramente, dándole al mismo tiempo fuertes palmotadas en la espalda). ¿Nun te acordas condo íbamos á escola xuntos? Pos búas $^{315}$ llafadas $^{316}$ tes $^{317}$ llevado del maestro ${ }^{318}$ por lo burro que eras; é decir (tocando en la cabeza), por lo duro de molleira ${ }^{319}$. A tabla ${ }^{320}$ de multiplicar i os estacazos del maestro traíante tollo.

BONIFACIO: (Retorciéndose la mano de dolor, y que Antonio le tuvo cogido durante todo el tiempo de la charla, se adelantará al proscenio retorciéndose las espaldas). ¡Pucha, qué brutos son estos gringos...! ¡Qué aspereza y qué rusticidad!

PEPA: $\quad$ (Reprendiendo con la mirada a Antón y dando cachetes acariciadores a Bonifacio). Mira tu, Bonifaciño, estos mozos nunca che saliron da aldea, ¿sabes?, i tanche un pouco montaraces.

ANTÓN: $\quad$ Pos... ¿como vamos a $\operatorname{tar}^{321}$ ? ¿Como señoritos? (Imitando la voz femenina). Oye, chico, ¿vos querés mandanga criolla linda? El home ten que ser home sempre; lo mismo pra decirye a úa moza (con voz meliflua) «tou tollo por ti; me derramo por tu cuerpo serrano», (con voz ronca) como pra darye a un home un centellazo, si chega el caso. (A Bonifacio). ¿É verdad ou non?

BONIFACIO: Amigaso. Vos sois un español indómito, castiso y agresivo que no conose su lengua.

ANTÓN: $\quad$ (Remedando). ¡Macanas ${ }^{322}$, chico, macanas! ¿La entendés vos acaso?

BONIFACIO: Ol rai ${ }^{323}$, xer amî324. Así se parla, amigaso.

ANTÓN: (Dándole la espalda). Párlete el demo, pedazo de pollín ${ }^{325}$.

BONIFACIO: (Yendo a sentarse al lado de Juanita). La prinsesa está triste... ¿Qué tendrá la prinsesa? ${ }^{326}$

\footnotetext{
314 Forma propia do castelán voseante.

315 Variante comarcal de boas. Do mesmo xeito peleyúa e sanúa.

316 Corrección manuscrita sobre lafadas; lapadas.

317 Corrixido sobre teis.

318 Cast., por mestre.

319 É posible que estea eliminado o $i$, para lograr a forma mollera.

320 Cast., por táboa (ou a comarcal traba).

321 Cast., por imos estar.

322 Lerias, parvadas.

323 Inglés all right.

324 Francés cher ami.

325 Cast., por burro.

326 Versos de «Sonatina» de Rubén Darío, recollido en Prosas profanas y otros poemas.
} 
ANTÓN: (Enseguida). A princesa tenche bioco ${ }^{327}$, muito bioco... i ganas de parola $a^{328}$ (guiñando un ojo al público).

BONIFACIO: (Sigue declamando en voz alta e hincando una rodilla en el suelo delante de Juanita). ¿Piensa; acaso en el prínsipe de Golconda o de China o en el que ha detenido su carrosa argentina, para ver de sus ojos la dulsura de luz ${ }^{329}$ ?...

ANTÓN: $\quad$ (Remedando). Xa empezou el mui cabrito;

pos un raio me parta

si antes de salir desta casa

nun vai haber un bon $\operatorname{cisco}^{330}$ ¡ $\mathrm{Ai}$, vai, ho!

PEPA: (Que seguirá preparando la cena y revolviendo de vez en cuando la olla). ¡Cuantas cousas sabe! ¡Estos homes de mundo aprenden tanto...! ¡Ah, Bonifaciño! ¿Tuviche en París de Francia, ho?

ANTÓN: $\quad$ ¿Este? ¡Boo...! Si, muyer, si tuvo; ¿Non iba a tar ${ }^{331}$ ? (Llevando el dedo a la sien). Pos ben se ye nota que tuvo y tá... en Babia. (Durante este tiempo, Bonifacio seguirá al lado de Juanita - que estará calcetando- y haciéndole mil gatuserías, poniendo la mano sobre el corazón, etc.).

BONIFACIO: (Sentándose bien). Perdonen, Vds.; ¿me desían?

ANTÓN: No..., nun deciamos ${ }^{332}$ nada...; que nun berrases tanto, que ibas a despertar el que tá dormindo de focico llargo ${ }^{333}$.

PEPA: $\quad$ Bueno, tu tamén tás de vena ${ }^{334}$... Decía si tuveras en París de Francia.

BONIFACIO: ¡Como no! ¡Oh, París! Cabaret «Mulen Rux» ${ }^{335}$. París es la quinta esensia $^{336}$ del plaser, es algo asombroso. ¡Pucha, qué teatros!

ANTÓN: Tate quieto con a pucha ${ }^{337}$. Tu tarías nesos sitios como entendido.

327 Meiró, meirolo, meco, netorría...

328 A corrección manuscrita suplanta a mecanografada calor.

329 Continúa o recitado co texto de Rubén Darío. Obsérvese que, esporadicamente, o autor non se acorda de sinalar graficamente o seseo do personaxe.

330 Emula o coñecido fragmento do Don Juan Tenorio de Zorrilla... ;Cuál gritan esos malditos! / Pero, ;mal rayo me parta / si en concluyendo la carta / no pagan caros sus gritos! (Parte I. Acto I. Escena I).

331 Parece corrixirse o presente ¿nun [h]a tar?

332 Non podemos saber se o autor utilizou conscientemente a forma paroxítona ou se, máis ben, esqueceu o til.

333 Fai referencia ao can

334 Cast., por vea.

335 Francés Moulin Rouge.

336 Var. de quintaesencia.

337 O autor xoga co dobre valor de pucha, segundo o idioma; para expresar sorpresa (Bonifacio) / substantivo co significado boina ou gorro (Antón). 
JUANITA: (Mirando muy coqueta a Bonifacio). Cuéntenos ${ }^{338}$ algo desos teatros i cines que vío. ¡Gústame a min tanto eso!

ANTÓN: ¡Ai! I a min tamén (con cara de bobo).

BONIFACIO: (Con énfasis). Mientras haiga vida en mi ser, recordaré eternamente aquella noche de invierno en que un cólega mío y un servidor fuimos al Apolo de Buenos Aires a presensiar una obra muy en boga entonces; medianeja, según mi amigo, que era périto en esa rama. La obra era -si mal no recuerdo- del dramaturgo argentino Rubén Darío, titulada D. Juan Honorio ${ }^{339}$.

ANTÓN: $\quad$ (Burlándose). ¡Ah, si, el ingueniero ${ }^{340}$ ! Xa lo cozo $^{341}$. Pos, si nun fora por ese Guan, el ingueniero, que me dixo «dégala, dégala...», allí hai un espanto de barbaridad.

JUANITA: (Llena de curiosidad). ¿Quen era...? ¿Quen era...?

ANTÓN: $\quad$ ¿El antroido ${ }^{342} !$ ¿Qué che importa? Atende al gringo, que pouco tempo che queda.

BONIFACIO: (Muy serio). No sé, pero creo no sería ese D. Juan. De todos modos, prosigo en mi narrasión. Ese D. Juan, hombre altivo y pendensiero gran burlador de mujeres, tiene la osadía de apostar con D. Luis Gemías ${ }^{343} \ldots$

ANTÓN: $\quad$ El demo te xema.

BONIFACIO: ..., prometido de Dña. Ana, de conquistarle la novia, consiguiéndolo tras varios lanses, en uno de los cuales pierde la vida D. Luis. Al mismo tiempo, y por cumplir la apuesta, rapta a la novisia Dña. Inés; pero, fíjense Vdes., D. Juan, hastiado del plaser, se enamora locamente y por ves primera de la casta e inosente Dña. Inés.

ANTÓN: $\quad$ (Rascando la cabeza por debajo de la gorra). Xa me tou dando cuenta del caso. Ahora que lo mismo pode chamarse Inés que Xuana (con intención). Solo que, aquí, quen vai a morrer ${ }^{344}$ é D. Juan. ¡Ai, si, ho! ¡Dígocho eo! (Encogiéndose de hombros y torciendo el gesto). Si, claro, el demo, cansado de... -é verdá, si, señor- métese fraile ${ }^{345}$; ¿verdá, compadre? Despois que tedes espolón ${ }^{346}$ y tades ben chíos de mundo... ${ }^{347}$ ( gui-

\footnotetext{
338 Cast., por cóntenos.

339 Como se sabe, Rubén Darío é nicaragüense. E o título da obra, Don Juan Tenorio, do vallisoletano José Zorrilla. O autor, para lograr a comicidade, xoga coa ignorancia de Bonifacio, acentuada tamén polo uso de formas populares como haiga, cólega, péreto, etc.

340 Antón bota man da gueada, nos castelanismos ingueniero, Guan e dégala, para ridiculizar a fachenda de Bonifacio. Tamén n'O pazo de Lugrís Freire se xoga con este fenómeno fonético para salientar o castelán postizo de Micaela.

341 Por conozo, utilizada coloquialmente por coñezo.

342 Var. de entroido.

343 Refírese ao personaxe de don Luis Mejía.

344 Cast., por vai morrer.

345 Cast., por frade.

346 Cast., por esporón.

347 O autor elimina y de carnaza.
} 
ñando un ojo), vides pral pueblo i embobais ${ }^{348}$ a estas inocentes con cuatro gringuadas que yes soltais. Ademais, tán ben sanúas ${ }^{349}$ i ben frescas. ¡Pápote, grillo! ${ }^{350}$ I pra acabar, tein a dibilidad de poñerse coloradas i trembar ${ }^{351}$ cuando yes chamais (con voz femenina) «mi prinsesa y mi vida». As probes esbabáyanse ${ }^{352}$ todas...

BONIFACIO: (Amoscado). ¡Pucha!, amigaso, vos parese agradaros la bronca. Si a vos os gusta esta linda muñequita y a mí me encanta, es porque ella lo merese... El más hábil triunfará. Pongamos los medios para ello.

ANTÓN: (De mal cariz). Tu poñerás os medios, pro eu vou poñer os extremos (estirando las manos).

BONIFACIO: Vos podés haserle la corte y yo requebrarla; ¿quién nos lo impide?

ANTÓN: $\quad$ A madre Celestina ${ }^{353}$ é quen debía impedillo (por Pepa).

BONIFACIO: Su corazón henchido de fragansia, llamará hasia sí al que ensienda en su alma la llama divina del amor (mirando embelesado a Juanita).

ANTÓN: $\quad$ ¡Oi, oi, oi, que cara de agua hai! Esto xa pasa de castaño obscuro. Ou é bobo ou faise. Si nun me falas en cristiano, nun che entendemos papa.

PEPA: $\quad$ ¡Ah, Antón, eso si que é falar! ¡Que boca de oro ten Bonifaciño! ¡Feliz da que lo lleve! ¡Ai, de oíllo, bríncame el corazón como si fora moza! (Con las manos cruzadas sacudirá el cuerpo).

ANTÓN: $\quad$ ¡Ja, ja, ja ${ }^{354}$, árdeche, carbayeira ${ }^{355}$ ! Era lo que faltaba.

JUANITA: (Mirando fijamente y parando de calcetar, muy melosa). Dígame ${ }^{356}$ que foi daquella Inés que enamorou tanto a D. Juan.

BONIFACIO: (Sonriente). ¡Pucha! Es sierto. Ya había obscuresido mi felisidad una nubesilla de tristeza; pero ya veo otra ves el sol; ¿verdad, mi sielo? (Pasándole una mano por la barbilla).

ANTÓN: $\quad$ Mirar y no tocar; peligro de muerte (dando con la cayada en el suelo un fuerte golpe).

348 Forma propia do bloque oriental por embobades. Do mesmo xeito, soltais e chamais, por soltades e chamades. A opción innovadora aparece rexistrada en pezas literarias de diversos autores. Valla como exemplo a composición «Vivide como poidais» de García Castro (1919).

349 Var. de sanoas, sanotas, ben sas.

350 A continuación, suprime Non tán enfarnadas de toda esa cotra que usan las afrancesadas.

351 Var. de tremer.

352 Esbabállanse, cáelles a baba.

353 Como se sabe, refírese á alcaiota da Tragicomedia de Calisto y Melibea (Rojas 1968: Volume II, 27).

354 Mantemos a ortografía orixinal, en lugar da actual ha.

355 Cabería interpretalo tamén como árdeche [a] carbayeira (véxase antes ¡Zúmbaye el perrengue!).

356 Antes, mecanografado, cuénteme. 
BONIFACIO: Pues aquella Inesita, de alma cándida y virginal, la rapta al fin D. Juan, el cual, arrebatado de furor y selos porque el padre se la niega y lo despresia, lo mata, teniendo que huir presipitadamente. Pero..., isi vieran aquella escena en que ambos se confiesan su amor! D. Juan, aquel famoso D. Juan, se ve hincado de rodillas ante ella y le dise en un éxtasis de adorasión divina (declamando exageradamente):

¡Ah! ¿No es cierto, ángel de amor,
que en esta apartada orilla
más pura la luna brilla
y se respira mejor? ...
Y estas palabras que están
filtrando insensiblemente
tu corasón ya pendiente
de los labios de D. Juan
y cuyas ideas van
inflamando en su interior
un fuego germinador
no ensendido todavía,
¿no es verdad, estrella mía,
que están respirando amor? ${ }^{357}$

ANTÓN: $\quad$ (Que durante todo este tiempo estará dando con una mano vueltas en el aire como imitando al organillo).

Nun é verdad, ángel de amor, que, aunque pinta mentira, aquí solo el llume brilla i esto vai de mal en peor?

BONIFACIO: (Continuando en el mismo tono y haciendo mil pantominas ${ }^{358}$ ).

¡Oh! Sí, bellísima Inés, espejo y lus de mis ojos; escucharme sin enojos como lo hasés, amor es. Mira aquí a tus plantas, pues, todo el altivo rigor de este corasón traidor que rendirse no creía, adorando, vida mía, la esclavitús ${ }^{359}$ de tu amor.

357 Nesta intervención de Bonifacio e na seguinte reprodúcense fragmentos da escena III do acto IV da parte I de Don Juan Tenorio de Zorrilla.

358 Var. coloquial de pantomima.

359 Esclavitud. Neste caso, e noutros anteriores, figura manuscrita a grafía seseante. 
ANTÓN: $\quad$ ¡Ai, ho! ¿I aprendiche todo eso «en aquella noche de invierno» con aquel périto cólega ${ }^{360}$ tou? Pos mira eu, sin salir de aquí, sei más que tu. Escuita:

La mujer que quiere a dos

no es tonta, sino entendida;

si una vela se apaga,

la otra se queda encendida ${ }^{361}$-si nun se apaga tamén ${ }^{362}-$. ¿Que

tal? ¿Soupo a queimado? Pregúntaye ${ }^{363}$ a la señorita Inés a que soupo (señalando a Juanita). (PEPA se reirá al oír esto $)^{364}$.

JUANITA: (Melosa). Nun ye fagan caso i acábeme de contar ese cuento.

ANTÓN: Teis razón chamarye cuento i llougo me parece que é el de a buena pipa (riéndose a carcajadas).

BONIFACIO: (Sin halagos). Nada, que murió Dña. Inés y más tarde murió D. Juan...

ANTÓN: $\quad$ Tán ben alón ${ }^{365}$ que Dios los tenga ${ }^{366}$ confesados $^{367}$.

BONIFACIO: (No dándose por entendido). ..., salvándolo con sus rezos del Infierno, a que estaba condenado.

ANTÓN: Pos allí taba ben, que é sitio calente. ¡Ai é, ho!

I colorín colorao, este cuento se ha acabado ${ }^{368}$;

a contallo noutro llao,

porque aquí nun colou.

Se oye la voz de Isidro cantar dentro: Mira, mira, Maruxina ${ }^{369}$, mira, mira como veño ${ }^{370}$... Esto lo repetirá en la puerta. Representará como de 50 a 60 años, usará barba, pantalón de labrador de pana muy raído y estropeado. Por debajo del pantalón se le verá una cuarta de calzoncillo de bayeta, terminando con escarpíos y madreñas. La chaqueta la traerá colgada de un hombro con parte de la camisa de afuera. Momentos antes, habrá salido Pepa. Todos se reirán al verlo.

\footnotetext{
360 Antón mantén as esdrúxulas de Bonifacio.

361 Cántiga popular.

362 Nota manuscrita.

363 No orixinal, preguntaya.
}

364 Neste punto figura eliminado o seguinte texto: ANTÓN dirá entonces: Ríe la comadre feliz y carnal / y un temblor cachondo le baja del papo / y muestra las ancas de yegua real... Son os versos cos que Ramón María del Valle-Inclán (1922: 56) se refire á raíña Isabel II na «Jornada primera» da súa Farsa y licencia de la reina castiza.

365 De acordo coa opción dialectal do resto da obra, debería usar alló.

366 Cast., por que Deus os teña.

367 Interpretamos que o texto manuscrito debe substituír a Pos Dios los descalce..., digo, descanse.

368 Nota manuscrita.

369 Como é frecuente «n» por «ñn», aquí non sabemos se o autor utiliza a forma galega ou a asturiana.

370 Corrixido sobre un vengo. Trátrase do coñecido cantar... Éche un andar miudiño, / miudiño, miudiño, / miudiño, miudiño, / o que eu traio. / Que eu traio unha borracheira / de viño, que auga non bebo. / Mira..., mira, Maruxiña, / mira..., mira como veño. 
ISIDRO: (Hablando dificultosamente, debido a la borrachera. Hará gestos de xelada $^{371}$. Estirando el cuello y cogiendo la barba). ¿Pos que pasa pra tanta festa? (Tambaleándose). ¡Ja, ja, ja; nin que fose cousa de risa! (Con misterio). ¿Por unde anda Pepa? (Señalando a Bonifacio). ¿I este que pinta aquí con esta facha? ¿Ou é el Negus? ${ }^{372}$ (Riendo). ¡Tá en calzonci$\operatorname{llos}^{373} \ldots$, ja, ja! ¿Viute Pepa así?

JUANITA: A V. si que lo vai a ver ${ }^{374}$. ¿Nun ye dá vergonza andar así todos os días por culpa das muyeres i del maldito vino? Todas as noites igual... ¡I un home casado!

ISIDRO: $\quad$ El que ye pica, ráscase i cada can llambe el sou. ¡Nun ye dá vergonza..., nun ye dá vergonza...! Pois peizme ${ }^{375}$ meyor salir a buscalla que esperallos na casa $i$, si non, pregúntaye $a$ este espantayo ${ }^{376}$ que sabe muito i tá de branco.

ANTÓN: $\quad$ Mui ben; aplausos del público ${ }^{377}$ (sentado junto al fuego).

BONIFACIO: Compadre, Vd. no me conose. Soy resién llegao de Buenos Aires. ¿Redordá al hijo de su vesino Pedro?

ISIDRO: ¡Ja, ja, ja! (Poniéndose serio). ¡Ah, Xuana! ¿Por unde anda Pepa? ¡Xa ten a escoba ${ }^{378}$ i el agua allí! (Aparece Pepa, la cual, al ver a Isidro, se echa las manos a la cabeza y grita).

PEPA: $\quad$ ¡Ah, borrachón, perdido! ¡Einda veis hoi pior ${ }^{379}$ que outros días! ¿Fuche ver a peleyúa ${ }^{380}$ ?

ISIDRO: $\quad$ (Tambaleándose se esconde detrás de Bonifacio, cogiéndolo por la chaqueta y lloriqueando). Pepa, Pepa, escuita: ¡no ${ }^{381}$ me pegues hoi, que é día santo!

PEPA: $\quad$ (Por toda contestación, se remanga y corre detrás de Isidro, el que no suelta a Bonifacio, y todos, unos detrás de otros, salen empujados; coge la escoba y empieza a arrearle escobazos a diestro y siniestro y, a pesar de los esfuerzos de Bonifacio por soltarse, no lo consigue, recibiendo parte de los escobazos que iban dirigidos a Isidro. Se procurará dar la mayor comicidad a esta escena). ¡Sinvergonzón! ¡Borrachón! ¡Muyerego! ¡Xa te allindarei eu ${ }^{382}$ ! ¡Hai que ferche como ás galiñas chocas ${ }^{383}$ ! (En este barullo, todos gritarán).

371 Xestos de que vén con frío.

372 Denominación utilizada para os reis e os emperadores de Etiopía.

373 Cast., por calzas, calzóns (ou a oriental calzois).

374 Cast., por vai ver.

375 Forma coloquial equivalente a paréceme.

376 Alternativa manuscrita que substitúe a al Negus.

377 Manuscrito para substituír a nos escaños.

378 Cast., por vasoira ou similares (vascallo, varredoiro...).

379 Var. de peor.

380 Pelandrusca.

381 Posiblemente se reproduza a oralidade, con desaparición da primeira nasal, de non me.

382 Xa te amainarei, xa che darei unha boa, xa te collerei por banda, xa te farei escarmentar...

383 Cando unha galiña estaba choca e non se lle querían botar ovos a chocar, era frecuente en moitos lugares mergullala en auga fría para que lle baixase a temperatura. 
ANTÓN: $\quad$ (Que estará sentado al lado de Xuana, se reirá, dando con la cayada fuertes golpes en el suelo). ¡Ánimo, Pepa, que eso si que che son macanas!

Al fin, Bonifacio se suelta y cae sentado en la tina, que está llena de agua, resbala y vuelve a caer, levantándose con un papel pegado, en donde se leerá «Próxima apertura. Los mejores perfumes y esencias». Pepa, mientras tanto, habrá cogido a Isidro y le tendrá metida la cabeza en la tina, mientras le propina fuertes cachuadas ${ }^{384}$. Si es posible que lo tenga con las piernas en alto.

ISIDRO: $\quad$ (De pie y despejado, ríe a carcajadas, mientras Bonifacio se arregla la ropa de mal humor). A culpa de todo esto tena el Negus. ¿Que vén facer tando tu? Ou é cousa de miña muyer... ¡Mira, esta plaza ${ }^{385}$ estache ocupada! (A Bonifacio). Si ques, vai protestar á Sociedad de Naciós ${ }^{386}$ i, si non, ponte en facha como Dios manda i nun andes en calzoncillos, porque, aunque $\mathrm{se}^{387} \mathrm{te}^{388}$ vexan algo, é o mismo; xa verás como nunca falta un rachado para un [d] escosido. Conque, tira pra diante ${ }^{389}$. A Xuana engañóuchema un i nun quere máis; ¿verdad, Antón? Si ques cenar ${ }^{390}$ con nosoutros, séntate i tan amigos... Pero, de maranfá..., $n a^{391}$.

BONIFACIO: Muchas gracias. Ustedes perdonen. ¡Boas noites! (Cantando). Un tropesón cualquiera dá en la vida... ${ }^{392}$.

ISIDRO: Bueno, a vosoutros nun vos quero ver chucharos ${ }^{393}$ a escondidas. ¡Á iglesia pa o domingo que vén! I, en eu ${ }^{394}$, non volvo máis á taberna nin a ningúa parte. (Guiñando un ojo a Pepa). Todo é pra ti; ¿eh, Pepiña? ¿Tá a cena feita? ${ }^{395}$

Nosoutros vamos á cena. Si algún quer ${ }^{396}$ acompañarnos, que veña sin escrúpulos, que a miña Pepa [t] en as maos tan limpias ${ }^{397}$, como a cara. E como é mala educación comer diante da xente, vamos a pechar ${ }^{398}$ a por$t a^{399}$. Conque, moi boas noites e perdonen ${ }^{400}$ as molestias.

384 Azoutas nas cachas, cachoadas.

385 Cast., por praza.

386 Plural propio do bloque central e de parte das falas galegoestremeñas (Costas 2013: 152), por Nacións.

387 No orixinal, como en máis casos, aparece «X» en lugar de «s», xe.

388 Cast., por che. Sorprende este teísmo, cando máis atrás vemos nun che se esqueiza e outros.

389 Contrasta con delante, utilizado nas narracións.

390 Cast., por cear.

391 Na lectura desta nota manuscrita dubidamos entre maranfá e marangá. Quizais se trate dunha formación sobre a raíz de maranfallar «confundir as cousas». Na, apócope de nada.

392 Fragmento do tango «Un tropezón» de Hoyos e Bayón (1927)... Un tropezón / cualquiera da en la vida, / y el corazón / aprende así a vivir.

393 Cast., na forma do enclítico, por chucharvos.

394 En canto a min. Outras lecturas posibles poderían ser I [b]en..., eu; I eu; I en [diante], eu.

395 Anotación manuscrita.

396 Var. de quere, utilizada máis arriba polo mesmo personaxe.

397 Cast., por limpas.

398 Cast., por imos pechar.

399 Corrección manuscrita para substituír a casa.

400 Cast., por perdoen. 


\section{REFERENCIAS}

Abuín González, A. + Ruibal, E. R. (2006), «Na procura da fórmula: o teatro popular de Manuel Lugrís Freire», Día das Letras Galegas 2006. Manuel Lugrís Freire, Coordinación de A. Santamarina Fernández e A. Tarrío Varela, Universidade de Santiago de Compostela, pp. 13-28.

Agrupación Artística de Armal (1936) Cousas d'outro tempo. Condo el cariño é de verdá... Edición y notas de G. Sánchez Jardón e I. Vares García, Ayuntamiento de Boal, 2006.

Álvarez Blanco, X. C. (1995) El serzo no louxado, [Eilao], [Mesa prá defensa del galego de Asturias ] MDGA.

Antoloxía de Poetas Populares de Cabana de Bergantiños (2013) Edición de X. M. Varela Varela, Concello de Cabana de Bergantiños.

Arias Campoamor, F. F. (1926) El trato, Edición de X. Babarro González en Galego de Asturias. Delimitación, caracterización e situación sociolingüística. Volume II, A Coruña, Fundación Pedro Barrié de la Maza, 2003, pp. 246-262. Existe outra edición de X. M. Suárez Fernández, As Figueiras, Asociación Cultural Rapalacóis, 2005.

Babarro González, X. (2003) Galego de Asturias. Delimitación, caracterización e situación sociolingüística. Volume I e II, A Coruña, Fundación Pedro Barrié de la Maza.

Babarro González, X. (2007) Évos un amaicer guapo. Aproximación á poesía en lingua galega do Principado de Asturias, 2. ${ }^{a}$ edición, Universidade de Vigo. Existe unha edición dixital, corrixida e aumentada, de 2010.

Bachicha (J. B. Deambrogio) + Contursi, P. (1928) «Bandoneón arrabalero», www.todotango.com.ar.

Bugallo González, R. (2009) Literatura dramática e teatro en galego do EoNavia, Universidade de Vigo.

Calvín Corredoira, A. (2013) Tiroliro, Taramundi, Asociación Cultural Os Castros.

Castro de Murguía, R. (1880) Follas novas, Habana, La Propaganda Literaria Madrid, La Ilustración Gallega y Asturiana.

Conde Valledor, A. (2000) Contos á tardiquía, Eilao, Mesa pola defensa do galego de Asturias.

Costas González, X.-H. (2013) O Valego. As falas de orixe galega do Val do Ellas (Cáceres - Estremadura), Vigo, Edicións Xerais de Galicia.

Cotarelo Valledor, A. (1981) Teatro histórico e mariñeiro (Hóstia, Beiramar e Mourenza), Edición, introdución e notas de Araceli Herrero Figueroa, Sada, A Coruña, Ediciós do Castro. 
Curros Enríquez, M. (1880) Aires d'a miña terra. Coleución de poesías gallegas c'un prólogo de D. José Ogea, Ourense, Tipografía de A. Otero.

Darío, R. (1896) Prosas profanas y otros poemas, Edición digital, Alicante, Biblioteca Virtual Miguel de Cervantes, 1999.

Dubert García, F. + Sousa Fernández, X. (2002) «Áreas lexicais galegas e portuguesas. A proposta de Cintra aplicada ó galego», Dialectoloxía e léxico, Editan R. Álvarez, F. Dubert García e X. Sousa Fernández, Santiago de Compostela, Instituto da Lingua Galega - Consello da Cultura Galega, pp. 193-222.

Fernández Acevedo, S. (2008) A herdade que nós temos. Historia e escolma da prosa en galego do Eo-Navia, Universidade de Vigo.

Fernández González, E. (2008) Grupo de teatro «Pico de Faro», Edición do autor, A Roda, Gráficas Ribadeo.

Fernández y Morales, A. (1861) Ensayos poéticos en dialecto berciano, León, Viuda e Hijos de Miñón. Existe unha edición facsímil, con estudios introductorios de J. A. Balboa de Paz, M. Gutiérrez Tuñón, A. Angueira Viturro e R. Álvarez Blanco, publicada polo Instituto de Estudios Bercianos, Ponferrada, 2003.

Fernández Rei, F. (1990) Dialectoloxía da lingua galega, Vigo, Edicións Xerais de Galicia.

Fernández Vior, J. A. (1998) Vocabulario da Veiga, Uviéu, Academia de la Llingua Asturiana.

Fidalgo Villaveirán, F. (1990) «La fulgurante década literaria del Eo», Ribadeo. Festas da Patrona, Comisión de Festas de Ribadeo.

Frías Conde, F. X. (1991) El xabaril que quería engalar e outros relatos, [Eilao], [Mesa prá defensa del galego de Asturias ] MDGA - Ámbitu.

Frías Conde, F. X. (2003) A literatura eonaviega contemporánea (Notas sobre literatura galega de Asturias), Eilao, MDGA / Mesa prá defensa del galego de Asturias.

García Castro, M. M. ${ }^{a}$ (1919) «Vivide como poidais», El Agricultor. Revista de Agricultura. Órgano de la «Sociedad de Labradores y Agricultores» de Riotorto y «Unión Agrícola y Pecuaria» de Villaodrid y Villameá. Revista editada en Riotorto nos albores do século XX, Edición facsimilar de 2007, Textos e coordinador da edición, Benigno Fernández-Salgado, Xunta de Galicia, pp. 2280-2281.

García Rivas, A. (2007) Contos, ducia e media d'eles, Uviéu, Trabe.

García-Galano, M. (1993) Mareaxes tapiegos, Uviéu, Serviciu de Publicaciones del Principáu d'Asturies.

García-Galano, M. (2010) Faraguyas, Uviéu, Academia de la Llingua Asturiana. 
Hoyos, R. de los... + Bayón Herrera, L. (1927) «Un tropezón», www.todotango. com.ar.

[Lamas Carvajal, V.] «Fr. Marcos da Portela» (1981) Catecismo do labrego, 15. edición, Vigo, Edicións Castrelos.

Lema Suárez, X. M. ${ }^{a}$ (2013) Costa do Solpor, Vigo, Edicións Xerais de Galicia.

López, J. M. ${ }^{a}$ (1928) Contos de polavila ou sean parolas e comentarios feitos ó son do lume, en varias cuciñas de unha aldea da provincia de Lugo, en noites de xeada, Alcalá de Henares, Imprenta de la Escuela Industrial de Jóvenes.

López Lajas, I. (1998) Seis sainetes valverdeiros, Edición e notas de X. H. Costas González (Asociación Alén do Val), Santiago de Compostela, Edicións Positivas.

Lourenzo, M. + Pillado Mayor, F. (1982) Antoloxía do teatro galego, Sada, A Coruña, Ediciós do Castro.

Noriega Varela, A. (1982) Do Ermo, Vigo, Editorial Galaxia.

Novoneyra, U. (1981) Os eidos, Vigo, Edicións Xerais de Galicia.

Núñez, T. (2005) Navia, nai, Deputación Provincial de Lugo.

Ogando, I. (2006), «Palabra, construción e transmisión. O teatro de Manuel Lugrís Freire», Boletín da Real Academia Galega, n. ${ }^{\circ} 367$, A Coruña, pp. 77-103.

Pimentel, L. (1981) Poesía enteira, Vigo, Edicións Xerais de Galicia.

Poncelas Abella, A. (1995) O mestre púxose louco, Ponferrada, Peñalba Impresión.

Prado «Lameiro», X. (1928) Monifates. Obra completa. Tomo III, Edición de M. Valcárcel, Estudio introductorio de B. Muñoz Saa, Concello de Ourense, 1995.

Quique de Roxíos (2002) Debaxo de nabis, sapis, Eilao, Mesa prá defensa del galego de Asturias (MDGA) - vtp editorial.

Rico Prieto, B. (2012) Algunhas maos, Uviéu, Trabe.

Rivas, A. G. (2009) Rebelión na caixa máxica, Uviéu, Trabe.

Rivas, A. G. (2010) As razóis d'Anxélica, Uviéu, Trabe.

Rojas, F. de (1499) La Celestina, [Volumes I e II], Edición, introducción y notas de J. Cejador y Frauca, Novena edición, Madrid, Espasa-Calpe, 1968.

Santamarina, A. (1982) «Dialectoloxía galega, Historia e resultados», Tradición, actualidade e futuro do galego. Actas do coloquio de Tréveris, 13 a 15 de novembro de 1980, Edición preparada por Dieter Kremer e Ramón Lorenzo, Santiago de Compostela, Xunta de Galicia, pp. 153-187.

Santiago, S. (1961) Villardevós, Vigo, Editorial Galaxia. 
Seco Orosa, A. (2004) «O trazado da fronteira oriental do galego en León e Zamora», en A Lingua Galega: Historia e Actualidade. Actas do I Congreso Internacional, Santiago de Compostela, 16-20 de setembro de 1996. Volume IV, Santiago de Compostela, Consello da Cultura Galega - Instituto da Lingua Galega, pp. 415-463.

Suárez Fernández, X. M. (1999) «Alejandro Sela y outros escritores en gallegoasturiano nel periódico El Aldeano de Castripol (1929-1933)», Actas das Primeiras Sesióis d'Estudio del Occidente (Castripol, 8 d'agosto de 1998), Uviéu, Academia de la Llingua Asturiana. Secretaría Llingüística del NaviaEo, pp. 59-66.

Suárez Fernández, X. M. (2006a) Unde letras falan. Antoloxía da poesía en galego-asturiano (1891-2006), Uviéu, Trabe.

Suárez Fernández, X. M. (2006b) ;Xa chegan os Quirotelvos! Gaiteiros, cuartetos y outros músicos populares nel estremo occidental d'Asturias, Xixón, Muséu del Pueblu d'Asturies.

Suárez Fernández, X. M. (2009) «El «Teatro Aldeano» da Biblioteca Popular Circulante de Castripol (1929-1934). Historia, estudio y edición das obras, Uviéu, Publicaciones Ámbitu.

Tato Fontaíña, L. (2006) «Manuel Lugrís Freire no teatro galego», Boletín da Real Academia Galega, n. ${ }^{\circ}$ 367, A Coruña, pp. 105-117.

Valle-Inclán, R. M. ${ }^{\mathrm{a}}$ (1922) Farsa y licencia de la reina castiza, Madrid, Artes de la Ilustración, Edición dixitalizada de 2010 de University of Toronto Robarts Library.

Vidal, M. (1920) Contos galegos d'antano e d'hogano, Santiago, Tip. de El Eco Franciscano.

Villar Ponte, A. (1922) Almas mortas, Edición facsímil, A Coruña, Edicións do Rueiro, 1978.

Zorrilla, J. (1844) Don Juan Tenorio. Drama religioso-fantástico en dos partes, Edición digital de J. J. Penalva, Alicante, Biblioteca Virtual Miguel de Cervantes, 2002. 
